\title{
ARCHITECTURE AND REFORMATION
}

A thesis submitted to the Faculty of Graduate and Post Doctoral Affairs in partial fulfillment of the requirements for the degree of

Master of Architecture

Jessica Wright

Carleton University

Ottawa, Ontario

(C) 2016 Jessica Wright 


\section{ABSTRACT}

In 2011, Correctional Services Canada closed Canada's oldest prison in continuous use, Kingston Penitentiary, as part of a larger reorganization and distribution of Canadian prisons. This thesis considers the abandoned prison site as an opportunity for productive and strategic architectural imagination. Through a series of modifications of the old prison -- removals and insertions of new buildings, and thorough redefinition of the grounds and buildings, in particular to do with the way the prison is inserted into its surrounding neighbourhood -- architecture here serves to support new thinking about correction and reformation. Through the application of the open-prison model and the re-integration of a "prison farm," along with architectural gestures that change the constrictive structure of Kingston Penitentiary, a new prison is born. The rate of crime in Canada has decreased in the last ten years yet despite this decline, the rate of incarceration has increased. The thesis asks, more profoundly: "How can architecture assist in reforming the Canadian prison model?" 


\section{ACKNOWLEDGEMENTS}

I would first like to thank my thesis advisor professor Janine Debanné, who thoroughly supported me throughout the entire process of this thesis. Her devotion to architectural ideas and theories and to their manifestation in buildings inspired and helped me to explore my work in new ways. Professor Debanné was always readily available whenever I had questions about my research; she allowed this thesis to be my own work, but lead me in the right the direction whenever she thought it was needed.

I am gratefully indebted to Jill Stoner, Director of Azrieli School of Architecture and Urbanism, Maeve McMahon, Associate Professor at the Department of Law and Legal Studies at Carleton University, and Yvan Cazabon, Associate Professor and Associate Director of Professional Programs at the Azrieli School. Their passionate participation, encouragement and recommendations, played an influential role in the completion of this work. 
TABLE OF CONTENTS

$\begin{array}{lc}\text { ABSTRACT } & \text { ii } \\ \text { ACKNOWLEDGEMENTS } & \text { iii } \\ \text { TABLE OF CONTENTS } & \text { iv } \\ \text { LIST OF ILLUSTRATIONS } & \text { vi } \\ \text { LIST OF APPENDICES } & \text { ix } \\ \text { INTRODUCTION } & 1\end{array}$

CHAPTER 1 The old and new prison model: A COMPARISON IN "HOW BUILDINGS CONTAIN"

CHAPTER 2 The History of Kingston Penitentiary: HINTS OF A NEW FUTURE DEEP IN THE PAST

CHAPTER 3 An Architectural Logic of Reform for Kingston Penitentiary

3.1 Preservation and Renewal: Old Walls, New Incisions

3.2 A Programme for Rehabilitation

3.3 Description of Interventions

CONCLUSION

37 
POSTSCRIPT

APPENDIX A

APPENDIX B

APPENDIX C

BIBLIOGRAPHY
Rethinking the programme as a post-prison culture

Architectural Programme for Reforming Kingston Penitentiary

Images of objects fabricated at the Kingston Penitentiary

Final Project Panels and Architectural Model

48 


\section{LIST OF ILLUSTRATIONS}

Page 5 Fig. 1: Sketch of Panopticon and photo of Presidio Modelo prison, drawn by Willey Reveley in 1791

Page $13 \quad$ Fig 2: Exploratory collage done by author: Overlay sketch of aerial view of Kingston Penitentiary on photo taken in 2005

Page $20 \quad$ Fig 3: Aerial View of Kingston Penitentiary showing buildings uses prior to prison closure in 2011 (Google Earth Photo annotated by Author)

Page $21 \quad$ Fig 4: Proposal for the Reformation of Kingston Penitentiary: Site Plan Indicating Architectural Modifications and New Zones (from fully secured to fully public).

Fig 5: Proposal for the Reformation of Kingston Penitentiary: Site Plan Indicating New Building Uses

Fig 6:View of the North walkway at the entry of the new site. A new fountain is placed in front of what used to be the conjugal visit housing. In the new programme, the stone walls that used to divide the six housing units, remain intact; trees grow where the inside of the houses used to be.

Page $29 \quad$ Fig 7: Exterior view of the entry at the primary market hall from King Street West, Kingston.

Page $\quad 30 \quad$ Fig 8: View of the entry in the primary market hall, located adjacent to the North walkway. The stairs leads to a second level, where there

is additional space to sell food. 
Page 31 Fig 9: View of a walkway in the resident zone. The walkway consists of the old walls that used to encompass the workhouse. The roof and interior of the building have been removed. A truss system with steel columns hold the structure together.

Fig 10: Axonometric view the west resident building. Residents tend to a vegetable garden that rests between the structure and Portsmouth Harbour. Stone texture in the view shows where the old walls are intact. outside vegetable garden. A curtain wall glazing system covers the interior hallway that faces the courtyard inside the resident zone. area, single bed, watercloset and sink.

Fig 13: Exterior view of the West resident building from a greenhouse. The curtain wall that faces an internal courtyard and hallways with inmates rooms can be seen in this view. resident gardening space adjacent to the St. Lawrence River. The resident common space is an area for inmates to socialize and participate in activities. 
Fig 18: Refurbished Toys for the Needy, by Kingston Penitentiary Inmates, c1950s.

and interior of the building have been removed. A truss system with steel columns hold the structure together

Fig 19: Kingston Penitentiary Inmate Hobbycraft Sale, Kingston Exhibition, 1952.

Page $\quad 47$

Fig 20: This water tower was originally part of the penitentiary farm. Construction was carried out by inmates and was completed in 1895.

The stones were quarried and cut by inmates.

Fig 21: "The Church of the Good Thief", it was constructed from limestone quarried, cut and transported to the site by convict gangs from the Kingston Penitentiary. The church was built between 1892 and 1894, and designed to include a mixture of Neo-Gothic and Romanesque architectural styles.

Fig 22: This buffet table was donated by Nancy Wright to the Stratford Perth Heritage Foundation for Fryfogel Tavern. It was made by inmates at the Kingston Penitentiary in the 1800 s.

Page $47 \quad$ Fig 23: Sir John A. Macdonald died in June, 1891, his coffin rested on a large wooden table in Kingston City Hall, a table made in the prison's furniture shop. 


\section{LIST OF APPENDICES}

APPENDIX A Architectural Programme for Reforming Kingston Penitentiary

APPENDIX B Images of fabrication related to the Kingston Penitentiary

APPENDIX C Final Project Panels and Architectural Model 


\section{INTRODUCTION}

"How many of us care about what happens inside a prison? If we are indifferent about the prison quality, we are certainly concerned about the released offender when he returns to our community, our neighbourhood, our street. If one believes that the two ideas are connected - what happens inside affects how the ex-offender behave on the outside - then almost everyone should care about prison performance and government oversight." 1

A prison is a structure or vessel in which people are legally held as a punishment for crimes they have committed or while awaiting trial. For architects, the prison is a difficult architectural topic: the prison's elements - walls, cells, communal buildings, gardens, are part of the architect's vocabulary, but the prison's mandate to limit, to interrupt, and to sever connections, is less conducive to the project of making architectural spaces. At the scale of the city, again, the dissociating prison building is a problematic element of the urban fabric. French architect Claude Nicolas Ledoux included no prison in his famous Ideal City of Chaux (1775). ${ }^{2}$ One can argue, with Ledoux, that prisons belong to non-ideal cities. They are part of a non-ideal reality. In the theoretical City of Chaux, Ledoux incorporated, instead, a Peace House, a Happiness Temple, and a courts of law building where conflicts between people were mediated. Citizens of the Ideal City never went to jail.

Criminologists, academics, lawyers and social scientists are beginning to address the faults of the federal prison systems in North America. ${ }^{3}$ How a society handles its unlawful members is always delicate, as is the balance between punishment and rehabilitation. In Canada as in the US, many people exit the prison system with mental health issues such as post-traumatic stress disorder, and reintegration into communities often fails as the years spent in prison only added to the individual's separation from society and ability to perform and cope within it.

${ }^{1}$ Scott D. Camp, Gerald G. Gaes, and Julianne B. Nelson, Measuring Prison Performance: Government Privatization and Accountability (United States: AltaMira Press, U.S., 2004), ix.

${ }^{2}$ Harry Francis Mallgrave, Modern Architectural Theory: A Historical Survey, 1673-1968 (United Kingdom: Cambridge University Press, 2009 ), $42-43$.

${ }^{3}$ David Brooks, “The Prison Problem," The New York Times, September 29, 2015, accessed June 25, 2016, http://www.nytimes.com/2015/09/29/opinion/david-brooks-the-prison-problem.html?_r=0.

John F. Pfaff, “The Causes of Growth in Prison Admissions and Populations,” SSRN Electronic Journal 28, no. 4 (July 20, 2012 ): 5-11. 
While it cannot be expected of our prisons to fully address all of these concerns in Canada, change is necessary and urgent. The Ottawa Citizen, Ottawa's local newspaper, reports on the dire need for prison reform on a weekly, sometimes daily, basis. ${ }^{4}$ In a spirit of thoughtfulness and empathy, this thesis considers the question of Canada's prison designs, and asks how the prison can become a place of reform from an architectural point of view. How can the architecture of the prison support a process which does not begin and end with "incarceration"? This thesis employs a former prison, Kingston Penitentiary, closed in 2011, in order to re imagine the architecture of rehabilitation of offenders.

There are many examples in contemporary architecture of old prisons converted into new uses, and in this sense, this thesis is atypical. The project of "converting a prison into a prison" contains an inherent tension, a friction that forces us to really think about how we understand crime, correction, reform, and reentry into society. The "prison into prison" rehabilitation/reuse project that forms the heart of this thesis, and which proposes a series of "reformations" of the architecture of Kingston Penitentiary, aims to enter into the very heart of what we hope the act of incarceration should achieve. The thesis considers the architectural questions of walls, restraints, limits, and separation, asking more specifically whether, (and how) to approach "holding and limiting" without "interrupting and severing." Can a prison be designed that serves the Correctional Service of Canada and the process of justice and retribution without the actions that tend to damage inmates and inhibit their successful reform and reentry into society? The thesis aims to uncover new directions that could be applied more broadly to prison design in Canada, whether renovations of old prisons, or entirely new ones.

${ }^{4}$ Mark Sutcliffe, “One day, we'll factor mental illness in to our criminal justice system," Ottawa Citizen, June 9, 2016, accessed June 27, 2016, http://ottawacitizen.com/opinion/columnists/sutcliffe-one-day-well-factor-mental-illness-in-to-our-criminal-justice-system.

Andrew Seymour, "Stats Show Bail Granted for Nearly All Who Ask, but Still Too Many Remanded in Custody, Critics Complain," Ottawa Citizen, June 19, 2016, accessed June 27, 2016, http://ottawacitizen.com/news/local-news/stats-show-bail-granted-for-nearly-all-who-ask-but-still-too-many-remand ed-in-custody-critics-complain.

Anne London-Weinstein, "Weinstein: End jail segregation of the mentally ill," Ottawa Citizen, June 2, 2016, accessed June 27, 2016, http://ottawacitizen.com/opinion/columnists/weinstein-end-jail-segregation-of-the-mentally-ill.

Tyler Dawson, "By the Numbers: Key Findings from the Innes Jail Task Force." The Ottawa Citizen, June 01, 2016, accessed June 05, 2016, http://ottawacitizen.com/news/local-news/by-the-numbers-key-findings-from-the-innes-jail-task-force.

Justin Piché, "Justin Piché: Orange Need Not Be the New Black." The Ottawa Citizen, June 10, 2014, accessed June 15, http://ottawacitizen.com/news/world/justin-piche-orange-need-not-be-the-new-black. 


\section{CHAPTER 1}

\section{The old and new prison model: A COMPARISON IN "HOW BUILDINGS CONTAIN"}

Prison researchers have commonly divided the prison system into two main categories: the archaic and vengeful "custodial prisons," and "decarceration" prisons. American Political theorist John Dilulio's introductory paper to a volume sponsored by the Bureau of Justice Statistics (1993) interprets the various goals of the criminal justice system: to punish, rehabilitate, deter, incapacitate and reintegrate. While these goals reaffirm social order, Dilulio asserts that the community would like these goals to be achieved "without violating the public conscience (humane treatment), jeopardizing the public law (constitutional rights), emptying the public purse (cost containment), or weakening the tradition of State and local public administration (federalism)."

Other analyses of prison performance such as those of criminologists Charles Logan and James Q. Wilson, advance that prisons cannot be held accountable for their ultimate outcomes. ${ }^{6}$ How well the inmates will behave after they are released, according to Logan and Wilson, is not a question the prison system can take on. The success of offenders' rehabilitation is something that plays out after the person leaves prison, they argue. Therefore, by requesting the prison system to rehabilitate and deter, we are asking it to achieve goals that fall outside the realms of it is intended to do, which is to punish people for crimes and symbolize fairness in the eyes of the public. But this argument is problematic. For prisons to punish only, and not try to punish and reform, seems wasteful. As Maya Schenwar illustrates in "Locked Down, Locked Out," prison systems that utilize the "eye for an eye" fairness are contributing to social problems which create a rippling effect that touches every corner of our society. ${ }^{7}$ It is therefore justifiable to ask the prison to achieve results that will only be expressed once outside the prison walls, rather than ones that are measurable inside only, and therefore, to challenge prisons to accomplish more than simply detain people. By asking this of the prison, we are challenging the prison to achieve results outside the prison, rather than the inside.

This thesis builds on the second position, that prisons should have goals of rehabilitation. A central idea, here, will be relationship and relational thinking: if we hope the prison to have an effect on what happens after prison, relational thinking makes sense. From an architectural point of view, the various zones of the site plan and the various parts and spaces in the buildings should be "related to each other," from the cell to the whole prison, and from inside the walls to outside the prison. This thesis will explore various prison

${ }^{5}$ John Dilulio et al., Performance Measures for the Criminal Justice System (Bureau of Justice Statistics , Princeton University, October, 11-15.

${ }^{6}$ Ibid.

${ }^{7}$ Maya Schenwar, Locked Down, Locked out: Why Prison Doesn't Work and How We Can Do Better (United States: Berrett-Koehler Pub, 2014 ), 3-6. 
models, especially around questions of architectural separations and connections, and will apply relevant findings to the renovation (or "reformation") of Kingston Penitentiary.

\section{Traditional Custodial Prison Models}

The most notorious custodial prison concept is the Panopticon designed by English Philosopher Jeremy Bentham in the late $18^{\text {th }}$ century. ${ }^{8}$ It is through the Panopticon that Bentham made his greatest impact on modern thought and on the theory of power. The design, which architectural historian Anthony Vidler has analyzed in depth, contains a prison in the shape of a circle, covered by a dome. ${ }^{9}$ The Panopticon is a prison model that suppresses its prisoners through its hierarchical architectural organization. On the outer circumference of the prison are the cells where the inmates reside. The depth of the cells creates a barrier system around the central core of the prison. This portion of the design is described as: "pan." Within the center of the design is a watchtower where the watchman or guard stays. From this location, he can monitor the prisoners in their cells. This portion of the design can be referred to as: "opticon. The strategic placement of the prison cells and watchtower allows the prisoners to sense that they are being observed at all times. Although it is impossible for a single watchman to monitor all of the inmates at once, the fact that the prisoners know they are being watched at some point effectively controls their behaviour.

${ }^{8}$ Jeremy Bentham and Miran Božovič, The Panopticon Writings (New York: Verso Books, 1995), 5-6.

${ }^{9}$ Anthony Vidler, The Architectural Uncanny: Essays in the Modern Unhomely (Cambridge, MA: M.I.T. Press, 1992), 194-195. 


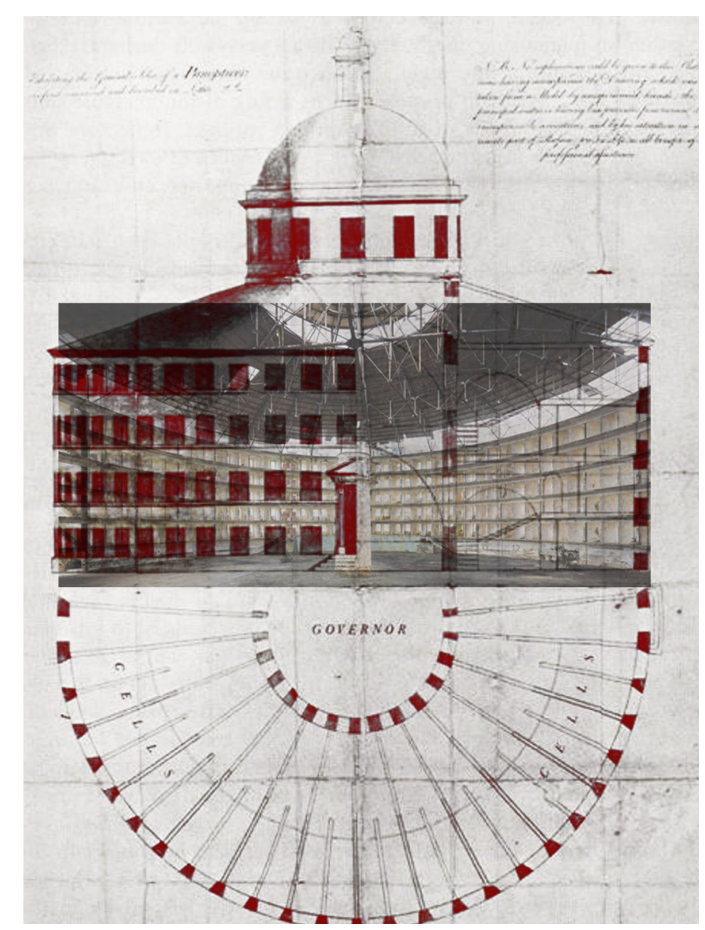

Figure 1: Exploratory collage done by author: Overlay drawing of Jeremy Bentham's Panopticon on photograph of the Presidio Modelo prison in Cuba.

The design of the Panopticon has lead to many controversial debates. French philosopher Michel Foucault has thoroughly analyzed and critiqued Bentham's ideas. In Discipline and Punish, Foucault uses the term "Panopticism" as a way to illustrate the weakness of punitive societies who subjugate their citizens..$^{10}$ Foucault describes the hypothetical prisoner of Bentham's Panopticon as being at the receiving end of asymmetrical surveillance: "He is seen, but he does not see; he is an object of information, never a subject in communication." As a consequence, the inmate polices himself for fear of punishment. The Panopticon is not merely, as Foucault thought, "a cruel, ingenious cage" in which subjects collaborate in their own subjection, but

${ }^{10}$ Michel Foucault. Discipline and Punish: The Birth of the Prison (New York: Vintage Books, 1975), 195-228. 
much more: constructing the Panopticon produces not only a prison, but also a god within it. The Panopticon is a machine which on assembly is already inhabited by a ghost, Foucault suggests. ${ }^{11}$

While the Panopticon can be appreciated from a theoretical standpoint, it is a primitive model that plays no role in rehabilitation, and further, is one that degrades inmates and does not prepare them for reentry into society. A prisoner in the Bentham system will only know what it is like to be "observed." There is no room for positive growth in such a place; this hostile environment can only lead to retaliation within the prison, and eventually in the "real world" once the prisoner has finished his or her term. How can we alter this model which prides itself on observing its inhabitants? We have come to a time where many in the corrections fields have come to believe that this model is ineffective. We now look at rehabilitative prison models, more holistic in their approach, and proven to have better outcomes on society, in the following section.

${ }^{11}$ Jeremy Bentham and Miran Božovič, The Panopticon Writings (New York: Verso Books, 1995). 


\section{The Modern Rehabilitative Prison Model}

\section{Halden Fengsel, Norway}

Who do we want as our neighbour? This is a question that resonates within the walls of the Halden Fengsel prison in Norway: this prison's central idea is to reform male offenders so that when they reenter society, people would not mind having them as neighbours. Successfully preparing a person who has strayed to being a good neighbour is the prison's measure of success. ${ }^{12}$ But how does this prison achieve this goal, from an architectural point of view?

On their webpage, Halden Fengsel presents a photo of two corrections officers, a man and a woman, warmly smiling at a young man. One assumes they are speaking to an inmate, and clearly, they are approaching that person with kindness. ${ }^{13}$ The prison rests in a picturesque wooded area, with meandering pathways, lush greenery and blueberry bushes. Pine and birch trees stand tall around the prison building, which is covered in a facade of dark bricks and elegant windows. Depending on the level of security, the facades alternate, from untreated wood to the very dark brick. The colours and materials of the structure are reiterated from the rocks and vegetation found on the site. The monolithic shapes of the prison buildings stand in contrast with the abundant landscape, creating lyrical tension. The only evidence which would suggest that Halden Fengsel is a maximum security prison is in the 25 foot high wall that surrounds the premises. It is often said, that the grounds of Halden Fengsel could be easily mistaken for a university campus, hospital or school. ${ }^{14}$ There are places within the prison that have no cameras at all, barbed wire or a guard tower on site. The prisoners are treated with respect and they are not considered as "bad people," only as: people like you or I, who have "done bad things," says prison warden Are Hoidal. ${ }^{15}$ With the mutual respect between guards and inmates -- guards even watch television with the inmates, for example -- as well as a high focus on rehabilitation, the recidivism rate in Norway is only 30 percent. This rate is 50 percent lower than North America's.

At Halden Fengsel prison, unconventional programs are used to recondition the prisoners. The prisoners live in apartment-style areas grouped in clusters of eight. Within his room, each prisoner can use a computer or be entertained by a flat screen television.

${ }^{12}$ Lorraine Mallinder, “Norway's Prison Without Bars: 'It's a trust thing,'” Al Jazeera Media, March 11, 2015, accessed June 14, 2016, http://www.aljazeera.com/indepth/features/2015/03/norway-prison-bars-trust-150303121441430.html.

13 "Welcome to Halden Fengsel," Halden Fengsel, April 1, 2016, accessed May 14, 2016, http://haldenfengsel.no/.

${ }^{14}$ Knut Egil Wang and Moment. "Inside Norway's Halden Prison,” The Story Institute, Accessed July 14, 2016, http://www.thestoryinstitute.com/halden/.

${ }^{15}$ Jeffrey Kofman, “In Norway, A Prison Built on Second Chances," Parallel, May 31, 2015. Accessed May 14, 2016. http://www.npr.org/sections/parallels/2015/05/31/410532066/in-norway-a-prison-built-on-second-chances. 
Unlike many standard prisons, cellmates have access to their own toilet and shower, accompanied with plush white towels to dry themselves. Each room has its own fridge, cupboards for storage and a newly built-in pine desk. The rooms, which are often compared to a hotel, look unto the lush skirt of greenery that wraps around the facility. ${ }^{16}$

Life inside the walls of Halden prison is meant to echo life outside the wall. Inmates participate in educational activities and employment. Such jobs include: working in stables, bike repair shops, timber mills or grow crops. Access to a variety of classes in general education and specific skill-training is provided for the prisoners as well. ${ }^{17}$ Some inmates even play in a band and they are able to practice their music in a well equipped recording studio located on the prison grounds. During their employment, the inmates are paid 10 kroner per day (10 CAD). Their day begins at 7:30 am and they return to their cells at 8:30 $\mathrm{pm}$. This structure is motivated in part by a key feature of the Norwegian sentencing system, which has no life sentences and stipulates a maximum term of 21 years. "If you have very few activities, your prisoners become more aggressive. If they are sitting all day, I don't think that is so good for a person. If they are busy, then they are happier. We try not to let them get institutionalized," states Are Hoidal. ${ }^{18}$ According to Hoidal, it has been a long time since there have been any fights between inmates at Halden; he also suggests that the entirety of the architecture and programme creates "softer people." 19 Hans Henrik Hoilund, one of the architects of Halden Fengsel describes how the purposeful act of making the prison look like the outside world allows the structure to feel less institutional. ${ }^{20}$ The exteriors are not concrete but made of bricks, galvanized steel and larch; the buildings seem to have grown organically from the woodlands. ${ }^{21}$ Halden prison has adapted a compassionate approach to punishment, one that transforms human flaw and error into constructive and useful actions.

\footnotetext{
${ }^{16}$ Knut Egil Wang and Moment, "Inside Norway's Halden Prison," The Story Institute, Accessed July 14, 2016, http://www.thestoryinstitute.com/halden/.
} 2016,

${ }^{17}$ Matt Essert, “Norway Treats Its Inmates Like People - the Result Is a System America Can Only Dream of," Mic, February 5, 2014, accessed May 10,

https://mic.com/articles/81233/norway-treats-its-inmates-like-people-the-result-is-a-system-america-can-only-dream-of\#.F3Mk5iQaU.

${ }^{18}$ Amelia Gentleman, "Inside Halden, the Most Humane Prison in the World," The Guardian, May 22, 2012, accessed April 15, 2016, https://www.theguardian.com/society/2012/may/18/halden-most-humane-prison-in-world.

${ }^{19}$ Ibid.

${ }^{20}$ William Lee Adams, “Norway Builds the World's Most Humane Prison,” Time, October 5, 2010, accessed May 12, 2016, http://content.time.com/time/magazine/article/0,9171,1986002,00.html.

\footnotetext{
${ }^{21}$ Ibid.
} 


\section{North Carolina, USA - "Reclaiming People, Reclaiming Places" Growing Change, Flip the Prison, North-Carolina}

Through his research, mental health therapist Noran Sanford found that approximately fifty prison sites have been left abandoned in North Carolina. These closures, which began in 1995 and continued for over a span of ten years, happened because fewer people were going back to prison due to a change in North Carolina's prison policies. Specifically, in 2011, the government concluded that probation violation -- responsible for half of the prison admissions - could be dealt with by parole officers as well as reentry councils, instead of incarceration. ${ }^{22}$ Today, many of the prisons have been vandalized and others have been left to decay. Sanford is attempting to rehabilitate several of these sites in conjunction with at a program that helps youth, ages 14 to17, who are out of home, out of school and on probation. Called "Growing Change," the program aims to transform these small decommissioned rural prison sites into sustainable farms and educational centers for youth and veterans. ${ }^{23}$ Sandford is working in conjunction with over ten foundations, including the North Carolina Department of Public Safety, the Center for Environmental Farm Study, the Kellogg Foundation and the Burt's Bees Greater Good Foundation, to further develop the Growing Change Program. The redevelopment of the sites --Sanford privileges brownfield sites in a state of abandon and decay --provide youth with leadership and entrepreneurial development skills. The project of converting old prison sites into educational farms redirects people on the edge of the criminal justice system toward an engagement that gives them life skills and job training while providing clinical support therapy. ${ }^{24}$ Troubled youth or returning veterans at a loss for job opportunities here have the chance to take on leadership roles while learning sustainable farming techniques. At the same time, these individuals can work towards a university degree in environmental science and sustainable agriculture. Through his initiative, Sanford envisions reviving old prisons in a very optimistic and constructive manner.

Currently in North Carolina, youth over the age of 16 are charged as adults. ${ }^{25}$ The "Growing Change" program attempts to work with the education and court system to convert the decommissioned prisons in North-Carolina to divert youth from the court

${ }^{22}$ Phoebe Judge, "NC Has Closed Nine Correctional Facilities Recently, Here's Why," WUNC. July 22, 2014, accessed July 02, 2016, http://wunc.org/post/nc-has-closed-nine-correctional-facilities-recently-heres-why\#stream/0.

23 "Our Mission Is Transformation," Growing Change, July/August 2011, accessed May 02, 2016, http://www.growingchange.org/.

24 Ibid.

${ }^{25}$ Maurice Chammah, "The 17-Year-Old Adults," The Marshall Project, March 6, 2015, accessed June 07, 2016, https://www.themarshallproject.org/2015/03/03/the-17-year-old-adults\#.KNeIRckZe. 
system. It is estimated by 2025, Growing Change will have helped 25 communities implement this model, which "flips the prison." The first prison flip is currently in progress at the former Scotland Correctional Centre in Wagram, Scotland County. The Scotland County site will also serve Hoke and Robeson counties. Currently Scotland County is one of North Carolina's poorest counties with the state's highest unemployment rate and highest food insecurity rate of $27.6 \%{ }^{26}$ This new educational farm integrates sustainable forward-thinking technologies and techniques including revival of brownfields. The old architecture of the prison buildings has been strategically altered in order to complement the new programme of the farm. At the Wagram prison site, for example, old cell blocks have been converted into aquaponic tanks, and guard towers into climbing walls. Previous brownfield space has been converted for the use of vermicomposting and beekeeping. An old "hot box" is being converted into a recording studio, and the prison bus is being converted into a traveling museum. ${ }^{27}$

\section{Prison Grounds: Bridging the Public and Private Planes Kerava and Suomenlinna, Finland}

The open prison is an informal establishment where prisoners serve their sentences with minimal security, are not locked up in prison cells and are permitted to take up employment while serving their time. ${ }^{28}$ The first open prison was HM Prison New Hall for women, in Flockton, West Yorkshire which opened as an experiment in 1933. The building became a male detention center in 1961, and in 1987 was re-assigned as a women's prison. ${ }^{29}$ The Finnish correctional system has refined the open prison concept to a much greater degree than other countries, including Canada. According to Dr. Tapio Lappi-Seppälä, head of the Institute of Criminology at the University of Helsinki, the open prison system plays an important role in the reduction of recidivism and crime rates in Finland. ${ }^{30}$ In the 1960s the incarceration rate in Finland was higher than most other countries in Europe. This is when the process of "decarceration" began, the latter taking three decades to complete. Today, Finland has one of the lowest rates of imprisonment in Europe. What made for the decarceration system's success was the reintroduction of inmates to normal life

\footnotetext{
26 "Health, Hunger, and Hope," Growing Change, February 6, 2015, accessed July 14, 2016, http://www.growingchange.org/reclaim-attain-sustain/health-hunger-hope/.

27 "Reclaim - Attain - Sustain" Growing Change, February 6, 2015, accessed July 14 2016, http://www.growingchange.org/reclaim-attain-sustain/

${ }^{28}$ Rae Ellen Bichell, "In Finland's 'open Prisons,' Inmates Have the Keys." Public Radio International, April 15, 2015, accessed July 01, 2016, http://www.pri.org/stories/2015-04-15/finlands-open-prisons-inmates-have-keys.

29 "New Hall Prison Information," Justice, updated August 30, 2013, accessed July 02, 2016, http://www.justice.gov.uk/contacts/prison-finder/new-hall

${ }^{30}$ Dr. Tapio Lappi-Seppälä, “Controlling Prisoner Rates: Experiences from Finland,” accessed May 09, 2016 http://www.unafei.or.jp/english/pdf/RS_No74/No74_05VE_Seppala1.pdf.
} 
through open prison systems. Through research, Finland's Criminal Sanctions Agency was able to discover that those who go through open prisons prior to re-entering society were 20 percent less likely to reoffend. ${ }^{31}$

A good example of one of Finland's open prison systems is "Kerava Prison," in Kerava. The building in which it is housed was built in 1891 as a school for boys aged seven to fourteen. It became a detention center in 1950, and in 2009 the open-prison project was applied, radically transforming the prison. In this seventy-four person prison, male inmates are given full access to the prison grounds. ${ }^{32}$ At Kereva, prisoners cultivate 200 hectares of agricultural land. The inmates also tend to their own gardens, housed in greenhouses. In turn visitors can walk through the grounds freely. Plants, flowers and vegetables grown on the site, firewood, wooden objects and metal produced on the site, all can be purchased by the public, as there is a market on the prison grounds. ${ }^{33}$

The prison of Suomenlinna located on the island of Suomenlinna, Finland, was established in 2009. The UNESCO world heritage site is another example of Finland's forward-thinking open prison system. ${ }^{34}$ The single-room, single-storey accommodations include shared kitchens, toilets, showers and saunas. There are large flat screen TVs within the common area, and a barbecue shelter is present near a tranquil pond. The site plan and photographs of the prison suggest that there is nothing severe about this place. The ninety-five male prisoners of Suomenlinna leave the prison grounds each day to do the township's general maintenance or commute to the mainland for work or to pursue an education. ${ }^{35}$ Their jobs pay for basic living costs, including food which they themselves purchase at the grocery store on the mainland. Money accumulated from a prisoner's employment can also be spent on the rental of a flat screen TV or small refrigerator for their room. Permits to the mainland which include overnight visits, are granted on a regular basis. ${ }^{36}$

${ }^{31}$ Rae Ellen Bichell, "In Finland's 'open Prisons,' Inmates Have the Keys." Public Radio International, April 15, 2015, accessed July 01, 2016, http://www.pri.org/stories/2015-04-15/finlands-open-prisons-inmates-have-keys.ys.

32 "The open prison Kerava (Finland) - February 2015," De Tour Buissonnier, April 05, 2016, accessed May 10, 2016, https://detourbuissonnier.wordpress.com/2016/04/05/la-prison-ouverte-de-kerava-finlande-fevrier-2015/.

${ }^{33}$ Ibid.

34 "Welcome to Helsinki Open Prison Suomenlinna Unit," The Scottish Government, Accessed May 02, 2016, http://www.gov.scot/Resource/Doc/925/0059982.pdf.

${ }^{35}$ Doran Larson, “Why Scandinavian Prisons Are Superior," The Atlantic, September 24, 2013, accessed May 10, 2016, http://www.theatlantic.com/international/archive/2013/09/why-scandinavian-prisons-are-superior/279949/.

${ }^{36}$ Ibid. 
This chapter has looked at "how buildings have contained" persons of the prison system over time. Each of these models takes a different position towards spatial constraints, control, arrangement of architectural elements, and programmatic layout. Two different types of prison systems, one punitive, one rehabilitative, point to two very different directions. As continuing research shows the positive outcomes of its application, and because, in the Canadian context, it is more reconcilable with aboriginal correctional philosophy, it seems very appropriate to give more attention to the rehabilitative model. We therefore ask here: How can architecture support rehabilitation? What architectural configurations, materials, sequences and spatial relationships, might be more conducive to rehabilitation? This thesis will further explore this model's relevance and test its potential on a former prison site in Canada: Kingston Penitentiary. 


\section{CHAPTER 2}

\section{The History of Kingston Penitentiary: Hints of a New Future Deep in the Past}

"[a penitentiary should be] a place by which every means not cruel and not affecting the health of the offender shall be rendered so irksome and so terrible that during his afterlife he may dread nothing so much as a repetition of the punishment, and ... that he should prefer death to such a contingency."

Christopher Thomson, on the construction of Kingston Penitentiary, The Upper Canada Herald, Kingston, 1831

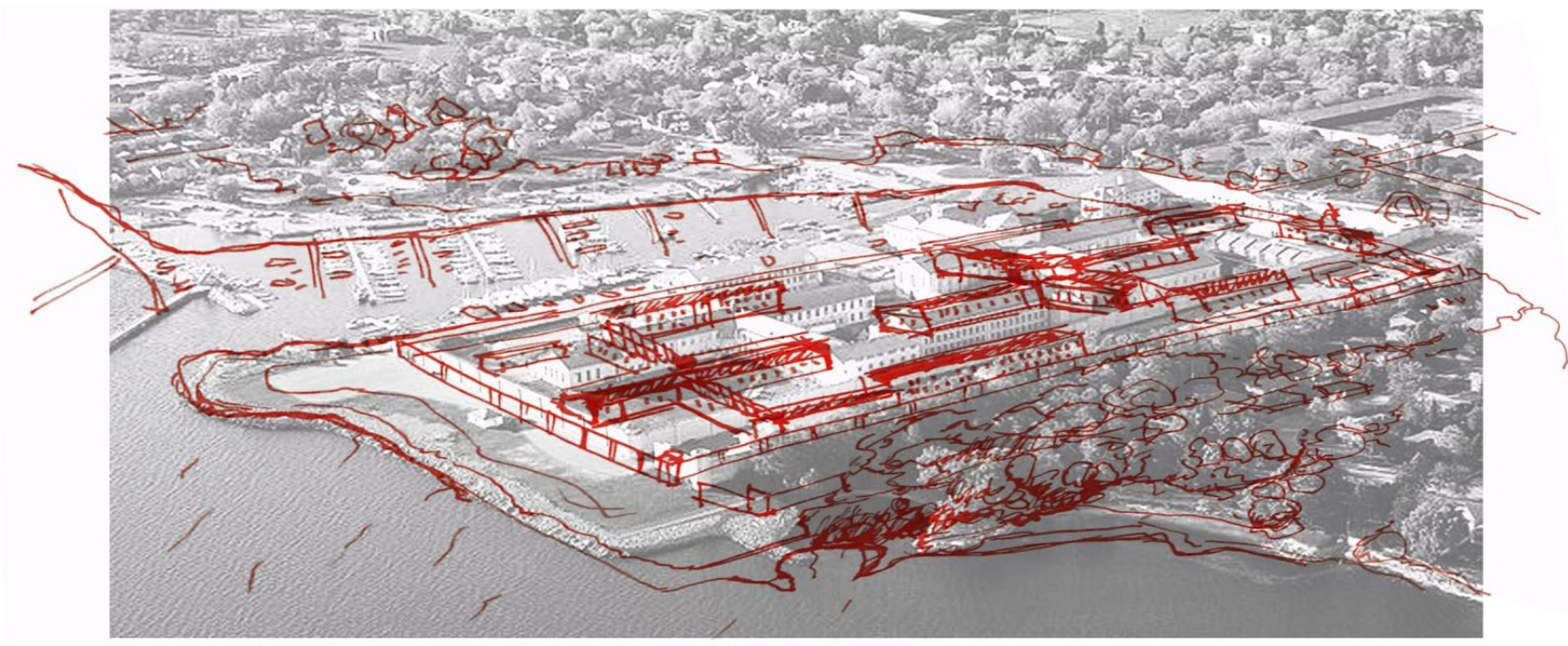

Figure 2: Exploratory collage done by author:

Overlay sketch of aerial view of Kingston Penitentiary on photo taken in 2005

For many decades, the most infamous prison in Canada was the Kingston Penitentiary, located at 560 King Street West, Kingston, Ontario. One can read Peter Hennessy's Canada's Big House: The Dark History of the Kingston Penitentiary (1999), for example, to gain a sense of the prison during its years of use. The idea of a provincial penitentiary was first introduced in 1826 to the Upper Canada House of Assembly by the Member from Frontenac, Hugh C. Thompson. The notion was first dismissed, and was then re-introduced in 1831. During this time, Thompson had visited and researched penitentiaries in other countries, including the Bridewell in Glasgow and the Auburn Prison in New York State. When the motion was reintroduced, Thompson issued a report which recommended five reasons for the construction of a penitentiary: the death penalty was not being 
executed for crimes less than murder, fines were unjust, local gaols lumped young offenders together with seasoned criminals, corporal punishment was improper and degrading, and banishment was unenforceable and often meant no punishment at all. ${ }^{37}$ For Thompson, a penitentiary should be administered as its name suggests: it should be a place where a man repents for his sins and amends his life. ${ }^{38}$ Prior to Thompson's suggestions, prisons were places made for holding prisoners prior to a trial hearing or as a means of punishment. The uniqueness of a penitentiary is that it could reform the criminal by separation from his former dangerous environment by imposing a routine of hard labour upon him. In the context of this thesis, it is interesting to discover that Kingston Penitentiary's earliest intentions were reformatory in nature.

The location for the Kingston Penitentiary on the coast of the St. Lawrence River in Hatter's Bay was suggested by Thompson. The site for Canada's first penitentiary was located on the East side of the Portsmouth Harbour where there was an abundance of limestone which could be quarried by the prisoners and British garrison for the construction of the prison. Hamilton was also considered as a site for the penitentiary, as it also had an abundance of limestone. Kingston was ultimately chosen as the site for the prison as its limestone was more durable than Hamilton's, which was of lesser quality. ${ }^{39}$ Today, still, the site is full of potential,and begs to be activated once again.

The construction of Kingston Penitentiary began in 1833. Limestone quarried from the site was used to construct a single large cell block in the form of a cross containing 154 cells within 5 tiers. The limestone sediments - stacked layers - were such that extraction was clean and precise. The main cell block building, designed on a massive scale, with its cruciform shape and central dome, is neoclassical in style, its four arms neatly organizing the surrounding space. In a sense this symmetry reflects the almost mathematical interior design of the main building which was based on the individual cell and expanded outward by multiples: in the South, East and West wings the cells were organized in blocks of five tiers, each tier containing twenty-two cells; two blocks arranged side by side and surrounded by a corridor formed a wing. The cell block design was strongly influenced by the Auburn prison in New York. ${ }^{40}$ Tiering the rows of cells essentially allowed for five levels of cells within a three storey building. The prison cells were designed to face a gallery walkway and exterior windows (which were 2.5 feet away from the walkway) on one side and an internal corridor on the other. The interior corridor divided the rows of cells in order to permit the guards to pace

${ }^{37}$ C. J. Taylor, "The Kingston, Ontario Penitentiary and Moral Architecture," Social History 12, no. 24 (1979): 385-408.

${ }^{38}$ Reilly, Emma, "The 'pen' of Kingston past," The Queen's Journal, October 14, 2005, accessed July 01, 2016, http://www.queensjournal.ca/story/2005-10-14/features/pen-kingston-past/.

39 “Penetentiary Stone Quarry,” Stone, accessed June 14, 2016, http://www.stoneskingston.ca/penitentiary-city/penitentiary-stone-quarry/.

${ }^{40}$ Ibid. 
through to monitor the prisoners. The design of the interior corridor allowed the guards to see into the cells through peepholes. As in Jeremy Bentham's Panopticon model, the prisoners were unable to witness the guards in the corridor. Originally, the North wing of the cell block did not contain cells, but rather, housed the dining hall, kitchen, hospital, keeper's hall, administration offices and residences for the senior administration officers and their families. ${ }^{41}$

When the prison was first built, each cell measured 2.5 in width, 8.3 in depth and 6'-7" in height. The cells remained this size until major renovations took place in 1895 and 1906. Each original cell had a small cot that was anchored to the wall that occupied almost the entire width of the cell when lowered. At the front of each cell was a grilled door that opened onto the gallery while at the back was a small window that allowed air to circulate through. The cells were narrow in size compared to precedent prison systems because the architects, John Mills, William Coverdale, and Edward Horsey, believed this was optimal for surveillance. ${ }^{42}$ While some of Kingston Penitentiary's buildings and arrangements are worth preserving, others, such as the cramped cell blocks, are not. They, instead, invite complete reinvention. But how might a cell block building be re-interpreted? This question will be answered further on.

Kingston Penitentiary officially opened in 1835 and registered six inmates on June first of that year. Five months later, there were sixty-two inmates, including women. By 1850, there were 410 inmates, including twenty-four women and girls. Women were incarcerated there during the prison's first century. ${ }^{43}$ By 1850 , Kingston Penitentiary had taken its final form. The prison went on to become the largest in Canada, and a notorious one at that. Even Charles Dickens would visit it.

Originally, a 12-foot high picket fence surrounded the prison. In 1945, during major renovations, the wooden fence was replaced by a concrete block wall along with towers and the north gatehouse. The wall now stands twenty feet high. Interestingly,

Kingston Penitentiary was, during its useful years, a productive landscape which once housed "what was reputedly the best prison hospital in North America, a complete prison farm, and the largest and best-equipped shops of any of the federal institutions." 44

\footnotetext{
${ }^{41}$ Dave Johnson, "Historical Overview of Kingston Penitentiary," United Way Kingston, accessed May 01, 2016, http://www.unitedwaykfla.ca/wp-content/uploads/2013/09/KP-history-from-Dave-Johnston.pdf.

${ }^{42}$ Susanna McLeod, "Kingston's solid foundation," The Whig, March 24, 2010, accessed May 3, 2016, http://www.thewhig.com/2010/03/24/kingstons-solid-foundation.

${ }^{43}$ Daniel Schwartz, "Kingston Pen Closing Recalls Dark History,” CBC News Canada, September 26, 2013, accessed May 10, 2016, http://www.cbc.ca/news/canada/kingston-pen-7-things-to-know-about-canada-s-notorious-prison-1.1865605.

${ }^{44}$ Dana Johnson, “Federal Heritage Building Review Office," accessed May 14, 2016, file://C:/Users/USER/Downloads/1989-032(F)\%20Kingston\%20Penitentiary\%20Buildings\%200N_OCRed\%20(10).pdf.
} 
Other buildings; industrial shops, sheds, stables and residences for the administration were also built on the 8.6 hectare compound. From limestone cutting, carpentry to rope making, the inmates at Kingston Penitentiary, would be makers of many things. All of these fabrication programs would certainly be appropriate elements in a renewed Kingston Penitentiary. The key would be to reorganize the relationships between them, and to reinterpret the notion of boundary and wall, according to a more contemporary vision of rehabilitation and reentry into society.

On April 19th, 2012, the federal government announced that Kingston Penitentiary would be closed. On September 30, 2013, Kingston Penitentiary formally ceased to be a federal prison. ${ }^{45}$ The prison was primarily closed as a money saving measure. As for the current state of the prison, there have been many different proposals for the future of the National Historic Site of Canada. Currently one can take a tour of the site, guided by a volunteer with a corrections background. The funds raised during public tours are given to the United Way's Kingston chapter. The public has enthusiastically responded, and tours are typically sold-out: in one weekend, 9000 tickets were sold and over $\$ 150,000$ raised. ${ }^{46}$ According to Justin Piché, an Associate Professor at the University of Ottawa, the tours, often led by former guards, are problematic as they give a biased view of what life might have been like at Kingston Penitentiary because they tend to glorify the protective work of guards during exceptional events such as escapes, while understating the daily hardship of inmates. He further critiques the tendency of "prison museums" to relegate brutality in prisons to a thing of the past, when in fact, the problem of brutal treatment of inmates is ongoing in the present. ${ }^{47}$ This thesis avoids this non-productive prison museum model by, instead, proposing to "convert" the shuttered prison at Kingston back into a prison, but one in which intention and architectural form have been significantly reformed.

\section{A Place of Fabrication and Making}

${ }^{45}$ Stevie Cameron, "Kingston Penitentiary: Canada's Most Famous Prison Closes Its Doors," The Globe and Mail, September 29, 2013, accessed May 10, 2016, //www.theglobeandmail.com/news/national/kingston-penitentiary-closes-its-doors-as-canadas-most-famous-prison/article14598900/?page=all.

${ }^{46}$ Ted Hsu, "Kingston Penitentiary to Close Its Doors after 178 Years," Ted Hsu, September 27, 2013, accessed May 10, 2016, http://blog.tedhsu.ca/2013/09/27/kingston-penitentiary-to-close-its-doors-after-178-years/.

${ }^{47}$ Justin Piché, "Kingston Penitentiary Tours Problematic, Argues Criminology Prof," CBC News, June 17, 2016, accessed May 10, 2016, http://www.cbc.ca/news/canada/ottawa/kingston-penitentiary-tours-problematic-1.3636838. 
"There is an admirable jail here, well and wisely governed, and excellently regulated in every respect. The men were employed as shoemakers, rope-makers, blacksmiths, tailors, carpenters, and stonecutters; and in the building of a new prison, which is pretty far advanced towards completion. The female prisoners were occupied in needlework."

Charles Dickens, American Notes, May, 1842

On his visit to Kingston Penitentiary in 1842, Charles Dickens remarked on the useful lives of prisoners at Kingston Penitentiary, listing in his journal all of the trades the inmates were involved in. The prison was not only a place of confinement, but a place of fabrication, hand-crafts and trades. In the morning, inmates would be marched off to their respective shops. On a typical day, the prisoner would start working at 5:15 am and end his tasks at 6:30 pm. Prisoners worked everyday of the week except Sunday. The choice of occupation was up to each, subject to approval by the prison authorities. Prisoners of Kingston Penitentiary did more than clear snow, garden, cook, launder clothes, and other basic tasks on the premises: they participated in stone cutting, farming, making furniture, cabinet making, tailoring, shoemaking, or working in the canvas shop where mailbags were produced and repaired. Prisoners also worked as utility workers within the prison, tending to the buildings' operations. ${ }^{48}$

By 1849, five manufacturers were selling goods that were made in the prison: E.P. Ross for shoes, J and W.S. of Stevenson Napanee for shoemaking, Brown for tailoring, J.P. Milner for Blacksmithing and S.T. Drennan for cabinet making. ${ }^{49}$ Products made at the Kingston Penitentiary were sold at retail shops in Kingston and we on display at the nearby Crystal Palace (now demolished), built in 1956 as the first permanent hall in Canada for the annual display of manufactured and agricultural goods. A large foundry of the hardware and metal castings for government buildings, including the metal railings at the Parliamentary Library, were all produced by the handicraft of inmates at Kingston Penitentiary. The prisoners also developed intricate tailoring skills, creating the garments for the North-West Mounted Police and the Indian chiefs and headmen.

Dennis and Blanchfield's Kingston Penitentiary: The First 50 Years, 1985, provides interesting anecdotes describing accounts of fabrication at Kingston Penitentiary. One can read that Samuel Drennan, an inmate and cabinetmaker, was commissioned in 1890 to furnish Alwington House on King Street in the anticipation of a visit from the Prince of Wales. Drennan created beautiful pieces of mahogany, walnut and rosewood, for the home. One of the pieces, an armchair with elaborate carvings, now sits on display in Memorial Hall at Kingston City Hall. While the finest homes in Kingston were dressed with furniture made in the Kingston Penitentiary, the prison's production of furniture was not just for domestic settings, as the Royal Military College also

${ }^{48}$ Susanna McLeod, "Dickens Thought Kingston 'a Very Poor Town," The Whig, August 20, 2013, accessed May 10, 2016, http://www.thewhig.com/2013/08/20/dickens-thought-kingston-a-very-poor-town.

${ }^{49}$ Bryan D. Palmer, “Kingston Mechanics and the Rise of the Penitentiary, 1833-1836," York University Journals 13, no. 25: 8-13. 
received a large portion of its furniture from the prison workshops. ${ }^{50}$ An article in Kingston's Beacon Herald tells the story of a woman named Nancy Wright, who donated a buffet made at the Kingston Penitentiary to the Fryfogel Tavern in Perth County. ${ }^{51}$ Wright recounts that, "In those days, the inmates were taught a skill, and they made furniture. Then the artisans came out from England and finished them, doing all the frills and furbelows and so on after that." 52

\section{Imagining a New Program at Kingston Penitentiary: How to organize the Site}

The following pages present architectural strategies aimed at fulfilling Kingston Penitentiary's potential to be a place of positive reform. To focus this investigation, this thesis proposes to re inhabit Kingston Penitentiary with a men's prison for nonviolent offenders. The new prison will focus on the rehabilitative and "decarceration" prison model. The model explored in this thesis will recover Kingston Penitentiary's traditions of craft fabrication, turning it once again into an active place of "making." The renovated prison will therefore include workshops and a market. The rectangular space now held inside the twenty foot tall walls is organized anew, to set up a journey of incarceration and return to society. The first gesture is to reduce the walled area by half. In the northern half, walls are metaphorically and literally knocked down to become ground surfaces. This northern area will contain programs where inmates and public meet each other. The southern half is walled, and contains inmate residence quarters, recreational areas, dining hall, healthcare, educational and daycare facilities, relaxing lodges, greenhouses, workhouses and land for farming.

The production of organic food cultivated by the residents will take place on the prison grounds. Inmates will grow food and care for the gardens. On the northern half of the prison grounds will be a market, providing a space where the residents practice their return into society as they interact with the public selling foods grown on the prison grounds. Located just east of the market is a woodshop where play-structures would be built. The prison would sell these inexpensively to the public one day per year, in the spring. Such interactions offer opportunities for the prisoner to have a gradual transition into the social world, contrary to the current system where transition is abrupt and can cause many challenges. This market programme marks the next-to-last step in the process of rehabilitation, and inmates would be allowed to work there during the day, returning into the prison's fully secure zone at day's end. Finally, once a prisoner nears the last weeks of his sentence, he takes part in roles that allow him to be an active member of society without supervision. To this end, the new Kingston Penitentiary is surrounded by an ornamental garden on the

\section{${ }^{50}$ Ibid.}

${ }^{51}$ Bruce Chessell, "A Match Made in Heaven,'" Stratford Beacon Herald, June 30, 2014, accessed June 11, 2016, http://www.stratfordbeaconherald.com/2014/06/30/historic-fryfogel-tavern-gets-generous-donation-of-antique-furniture.
${ }_{52}$ Ibid. 
west river shore, immediately outside the prison walls. Here, the inmate can occupy a zone just outside the prison. The flowers and herbs are there for the viewing, offered freely to the public as a goodbye gift. This allows for the prisoner to have a gradual transition, contrary to the current system which is abrupt and can cause many challenges. South-west is a garden where visitors can pick fresh berries for a small fee. This garden is adjacent to the resident housing, the proximity of the locations allows the inmates to easily upkeep the berry field. 


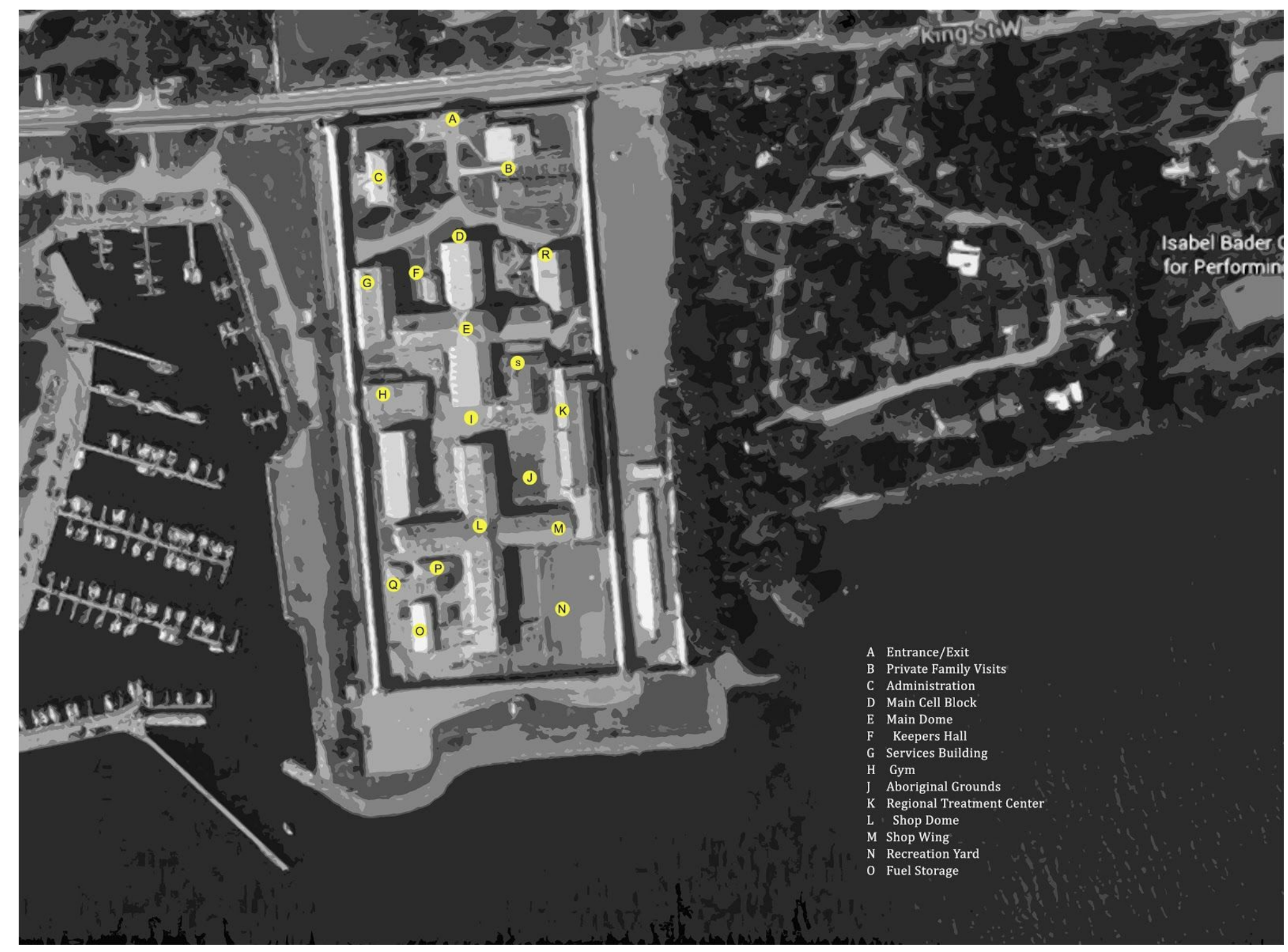

Figure 3: Aerial View of Kingston Penitentiary showing buildings uses prior to prison closure in 2011 (Google Earth Photo annotated by Author) 


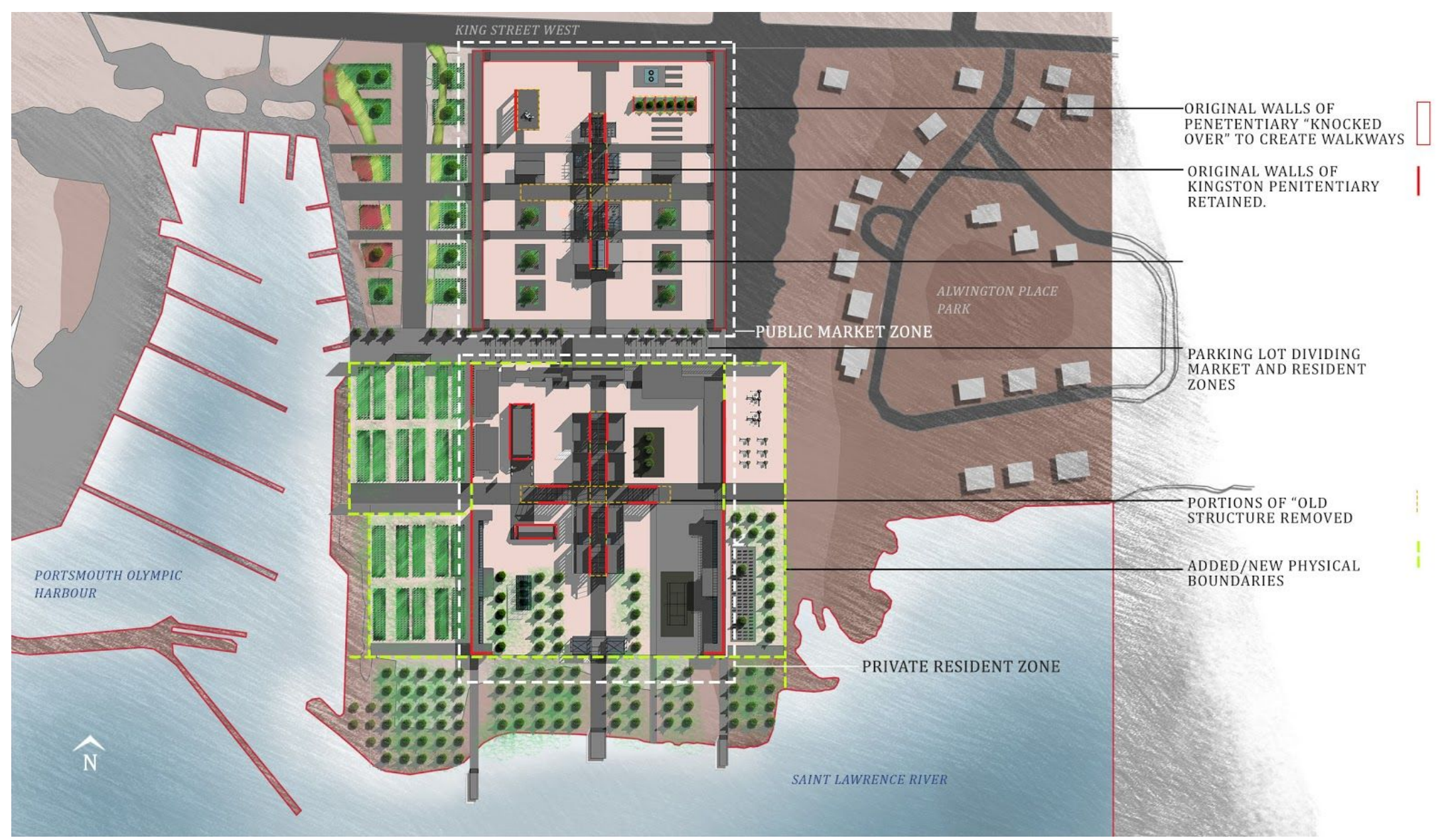

Figure 4: Proposal for the Reformation of Kingston Penitentiary: Site Plan Indicating Architectural Modifications and New Zones (from fully secured to fully public). 


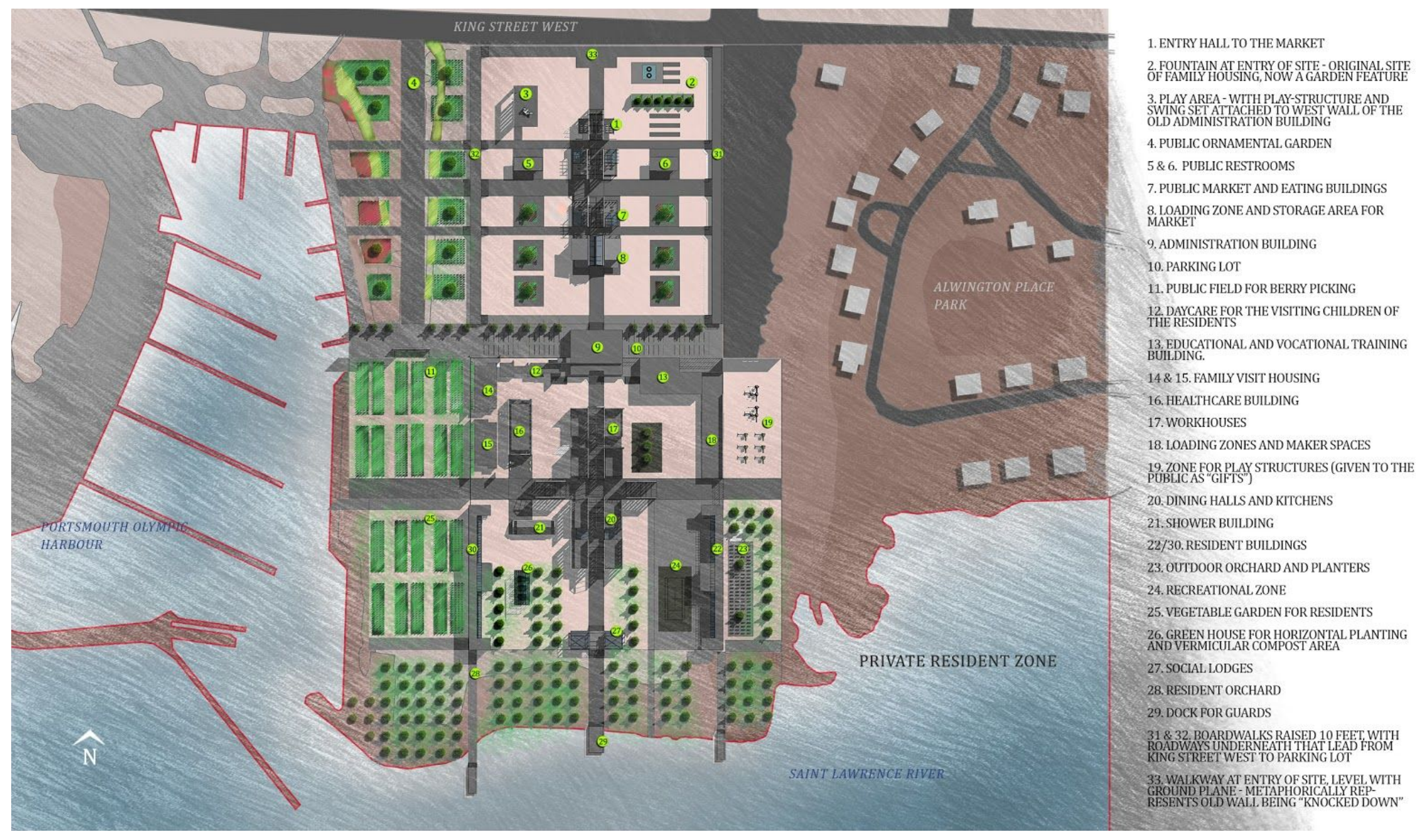

Figure 5: Proposal for the Reformation of Kingston Penitentiary: Site Plan Indicating New Building Uses 


\section{CHAPTER 3}

\section{An Architectural Logic of Reform for Kingston Penitentiary}

\subsection{Preservation and Renewal: Old Walls, New Incisions}

The Kingston Penitentiary received a historical designation in 1990, and now figures on the National Historic Sites list. ${ }^{53}$ As is, site and architecture are hauntingly beautiful. ${ }^{54}$ As a series of buildings, the prison is a protected site. Nonetheless, the prison begs to be transformed and revived. The architectural interventions proposed in this thesis are therefore in the spirit of architectural preservation. Transformations to the original constructions are therefore conceived in a way that does not impede the visitor or inmate being able to "reconstruct the old prison mentally." Nonetheless, the prison begs to be transformed and revived. It seems only natural to think of cutting into the heavy stone walls in order to bring light, air, new breath, into this ensemble. The oppressing walls of the prison, which were constructed by the prisoners from native limestone, are a poignant homage to the site's history. How, though, to bring openness to a stone building, where one that must still, to some degree, confine?

In the 1996 documentary directed by Murray Grigor and President of the Fondazione Querini Stampalia, Egle Trincanato, poetically describes how the Venetian architect Carlo Scarpa (1906-1978) renovated the Venetian palace in 1963. Trincanato illustrates how "above all, (Scarpa) was exceptionally skillful in knowing how to combine a base material with a precious one." 55 Scarpa mastered the art of maneuvering the relationship between old and new, creating material joints where a new material reveals an old one. His tectonic language and refined manipulations of materials allowed him to reveal the history of the old building where it was appropriate. ${ }^{56}$ In an interview, editor of the first monograph of Scarpa, Tom Wright, described the influence of the architect's works in today's world: "The (other) thing that's important about Scarpa is that he was promoting ideas of

53 "Kingston Penitentiary National Historic Site of Canada," Historic Places." accessed June 11, 2016, http://www.historicplaces.ca/en/rep-reg/place-lieu.aspx?id=13265.

${ }^{54}$ Kingston Penitentiary, self-guided tour, Kingston, Ontario, May 21, 2016.

55 “Carlo Scarpa - A Profile,” Directed by Murray Grigor and Egle Trincanato, Italy, 1996. 1996, Accessed April 02, 2016, https://www.youtube.com/watch?v=9KxXgkEWK1U.

${ }^{56}$ Ibid. 
environmentalism and craft way before they took on the status they have now. There's an element to his work that is very relevant now - in a way that may not have been understood at the time." 57

After the closure of Kingston Penitentiary, we find ourselves asking, "how can this site be revived but not forgotten?" Carlo Scarpa's approach to finessing the combination of old and new structures is a useful model. His architectural logic, where massive elements are combined with finer materials, like glass and metal, is applicable to the Kingston Penitentiary. With the twenty foot walls that encompass the compound and the abundance of commanding buildings within the site, the fitting measure would be to establish new relationships between them through "dissections," or cuts. The dissection of the prison walls and insertion of more delicate materials, as in Scarpa's works, would allow the site to be metaphorically "susceptible" to new connections and new relationships. Breaking up the old stone masses creates a more sympathetic architecture which addresses the rehabilitative nature of the new programme. Openings and incisions here create "vulnerabilities" that are contrary to the original authoritarian and punitive architecture. As for questions of heritage, the modifications can be made so as not to compromise the structure's historical identity, while activating new affinities and relationships to the surrounding site. The act of connecting to the "outside world" is important to a rehabilitative scheme. This was recognized in the case of Halden Fengsel prison, where it was important for "the outside world to echo the inside." However, as the new programme emphasizes the recovery of its dwellers, it is also important that there be a sense of enclosure. Retaining a portion of the existing walls will aid in maintaining a sense and space of safety and security on the compound.

\subsection{A Programme for Rehabilitation}

The prison program is ideological, and suggests a vision for what activities in a person's daily life makes them, or helps make them, a "good person." This is a simplified statement, but it is nonetheless true. The prison program is loaded and important; it is a carrier of a vision for how to reform people. A prison in Brazil, for example, exchanges four days off for every book read: the inmate's daily actions - reading, farming, cooking, washing, or making things - are roadways to rehabilitation. ${ }^{58}$

The program in this thesis proposition is inspired by the case studies treated in Chapter 1, and by Kingston Penitentiary's history of fabrication. More fundamentally, though, the old prison, its site plan and its buildings, are here reorganized according to the

${ }^{57}$ Tom Wright, "Introducing the Carlo Scarpa Monograph," Phaidon, accessed April 11, 2016,

http://ca.phaidon.com/agenda/architecture/articles/2013/june/26/introducing-the-carlo-scarpa-monograph/.

58 "Brazil Prisoners Reading Books to Shorten Their Sentences," The Telegraph, June 26, 2012, accessed May 11, 2016,

http://www.telegraph.co.uk/news/worldnews/southamerica/brazil/9356129/Brazil-prisoners-reading-books-to-shorten-their-sentences.html. 
principle of "spatial relatedness." In other words, this proposition strives to establish relationships where previously separations existed. These relationships are precisely organized here, to strengthen the prison's ability to make the inmate more connected to his environment, and more aware of how his actions are tied into a larger scheme. The site plan strives to be a harmonious whole where relationships - be they social, environmental or physical - are active in the inmates' lives. In old Kingston Penitentiary, people felt totally disconnected from their environment. Riots happened. When the prisoner feels connected to their place of life, they are likely to make positive contributions to it, making it more beautiful, and finding a sense of purpose while they are living there. The following are statutes which will help the new architectural programme of Kingston Penitentiary achieve its rehabilitative model:

Public Safety: It is important for the residents (inmates) and public to live in place where they feel protected. Residents of the programme will be non-violent and non-threatening offenders.

Promoting Secure Communities: By creating two separate communities for the inmates, a residence and public market, the new design provides areas for two types of interactions. The residential area is protected and walled; within it, the inmate can find a space to rest, reflect, work quietly, and rekindle their spirit. The market area provides an opportunity for the inmate to have a glimpse of the external world - one that they will soon be a part of. By permitting the prisoners to merge with the public under supervised conditions, and solely for the purpose of working, a steady transition of the inmate as he prepares to rejoin community, is possible.

Doing Justice: It is crucial for justice to be served in the rehabilitative process, for the inmate and for those who the crime was committed against. As said by Martin Luther King Jr., "Human progress is neither automatic nor inevitable... Every step toward the goal of justice requires sacrifice, suffering, and struggle; the tireless exertions and passionate concern of dedicated individuals. $" 59$ Through the dedication of hard work - cultivating food on the premises for themselves and the public - offenders are working towards their own progress.

Reduction of Recidivism: In 2008, the recidivism rates in Canada were 50-80\%. This number is alarmingly high. Many sources suggest that rewiring the brain through repetitive practice of pro-social behaviors and positive reinforcement is highly effective. Preparing inmates to be working members or society is also a vital key the in the reduction of recidivism. According to Gary Mohr, director of the Ohio Department of Rehabilitation and Correction, "When people turn these inmates down for jobs or

59 "MLK Week," New York University, accessed May 11, 2016, https://www.nyu.edu/life/events-taditions/mlk-week.html. 
housing we really have developed a second class of citizens that often people think are less than human beings. Prisons need to take an evidence-based approach at rehabilitation, train inmates and give them the tools they need to be productive citizens." 60 By giving the inmates the skills they need, an education and work experience, we are lessening the chance that they will repeat their criminal actions.

The participation in Meaningful Activities (Purpose): The new Kingston Penitentiary provides the inmates with activities that will allow them to have a sense of purpose. In 2014, a group of sixty inmates in Orange County, South Carolina, built a playhouse that was auctioned for charity. Through the process of building the playhouse, one inmate, Chris Herdt, told the Los Angeles Times: "No one wants to be in here, but when we build together on a big project, it's a motivator. It gets our mind off the negatives, the gangs, our race. We work together and it gives us a purpose." 61 Having a goal to work towards allows the inmates to feel a sense of accomplishment. Providing the inmates with an opportunity to cultivate healthy food for themselves and their community, and to build things that the public will appreciate (such as play structures), gives them an objective. Other designated areas on site that promote meaningful activities are: a meditation area, reading and educational center and workhouses.

Re-integration into the Community: Creating a public market adjacent to the residential zone provides a place where inmates can rub shoulders with other members of society. There, the inmate will better be able to face the reality of life in society, and the challenges that await, as their journey through incarceration comes to an end. The provision of a public market on the site also allows for the external society to be more accepting of the inmate's condition. The prison provides inexpensive organic produce and wooden craft objects that neighbours are happy to have access to. This gradual exposure to the public grants the prisoner an opportunity to be seen on an equal plane as the rest of humanity.

${ }^{60}$ Jon Wysochansk, "Prison Programs Aim to Reduce Recidivism, Give Inmates Job Skills," The Morning Journal, June 01, 2014, accessed June 11, 2016, http://www.morningjournal.com/article/MJ/20140106/NEWS/140109535.

${ }^{61}$ Mai Tran, "Inmates Build a Sense of Purpose While Creating a Playhouse Entry," Los Angeles Times, August 31, 2004, accessed May 11, 2016, http://articles.latimes.com/2004/aug/31/local/me-playhouse31. 


\section{An Architectural Logic of Reform - Strategies for Reforming the Architecture of Kingston Penitentiary}

\section{Walls Becoming Walkways:}

The programme for a renovated Kingston Penitentiary is diverse, as seen above, but two elements embody and organize the fundamental dichotomy between prison and society: the market and the residence. The market, place of meeting of public and prison, is the one place where the public comes in, and the residence, the one place where the prisoner is really alone.

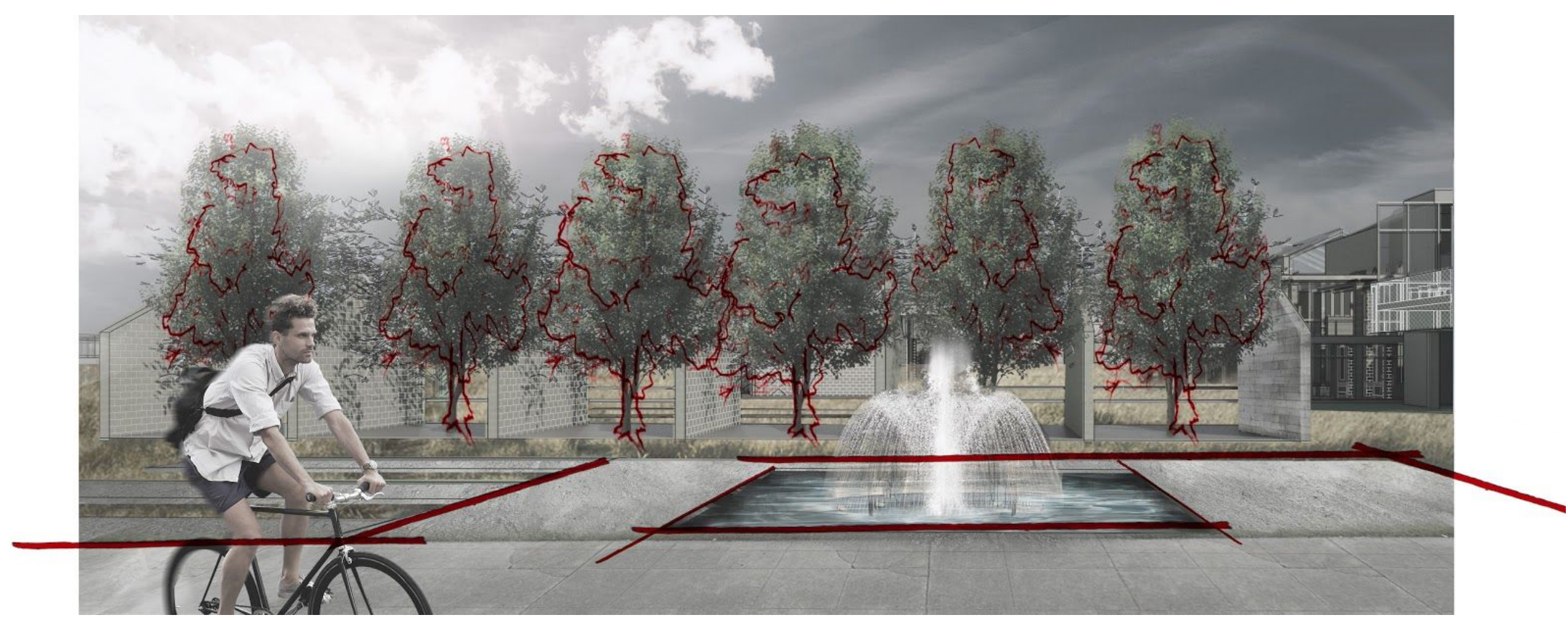

Figure 6: View of the North walkway at the entry of the new site. A new fountain is placed in front of what used to be the conjugal visit housing. In the new programme, the stone walls that used to divide the six housing units, remain intact; trees grow where the inside of the houses used to be.

The market will be located on the northern end of the grounds, and organizes a transition from King Street West to the Residential Zone. The original twenty foot high prison walls that once surrounded this portion of the site will be removed and metaphorically laid horizontally as a stone surface to create walkways that border the market buildings and landscape. Above the East and West 
stone walkways is a wooden boardwalk, elevated ten feet above the ground. These elevated boardwalks also delineate the entrance to a parking lot and loading zone.

West of the site is the Portsmouth Harbour. Between the Harbour and adjacent walkway is a manicured landscape that connects the two elements. The northern wall of the market zone is removed and metaphorically laid flat: a stone surface set flush with the sidewalk along King Street West, and the surrounding ground plane. This stone surface, a kind of reception plaza, measures in width the exact dimension of the original prison wall height. The shift from vertical wall to stone floor creates a sense of continuity and openness with the neighbourhood, inviting the public in. The Market Halls, which were once the main cell block, will utilize major portions of the east and west walls as enclosures for the new programme. To this end, parts of the former cruciform cell block are removed, including the east and west wings and the central dome. The former cruciform cell block is now a grouping of four discrete buildings making up a centralized Market Hall. The building will be enclosed with the walls of the original buildings on the east and west sides, and the remaining enclosures will be dressed with lighter-weight materials such as a glass curtain wall and perforated metal sheets.

The four main buildings of the Market Hall are divided into: a Main Hall, two Secondary Halls and a Loading Hall. The Main Hall is directly adjacent to King Street West, welcoming visitors to enter the building. The structure will be enclosed with an operable glazed roof system which will allow for natural light and air to enter the space when needed. The secondary Market Halls will be partially enclosed, and partially open to the air. The intention is to provide pavilion spaces for the vending of produce cultivated on the site's grounds. The Loading Hall is a structure which acts as a storage and preparing facility for goods transported from the residential zone. This is an enclosed building, which is comprised of the original Kingston Penitentiary walls, curtain wall systems and concrete walls. 


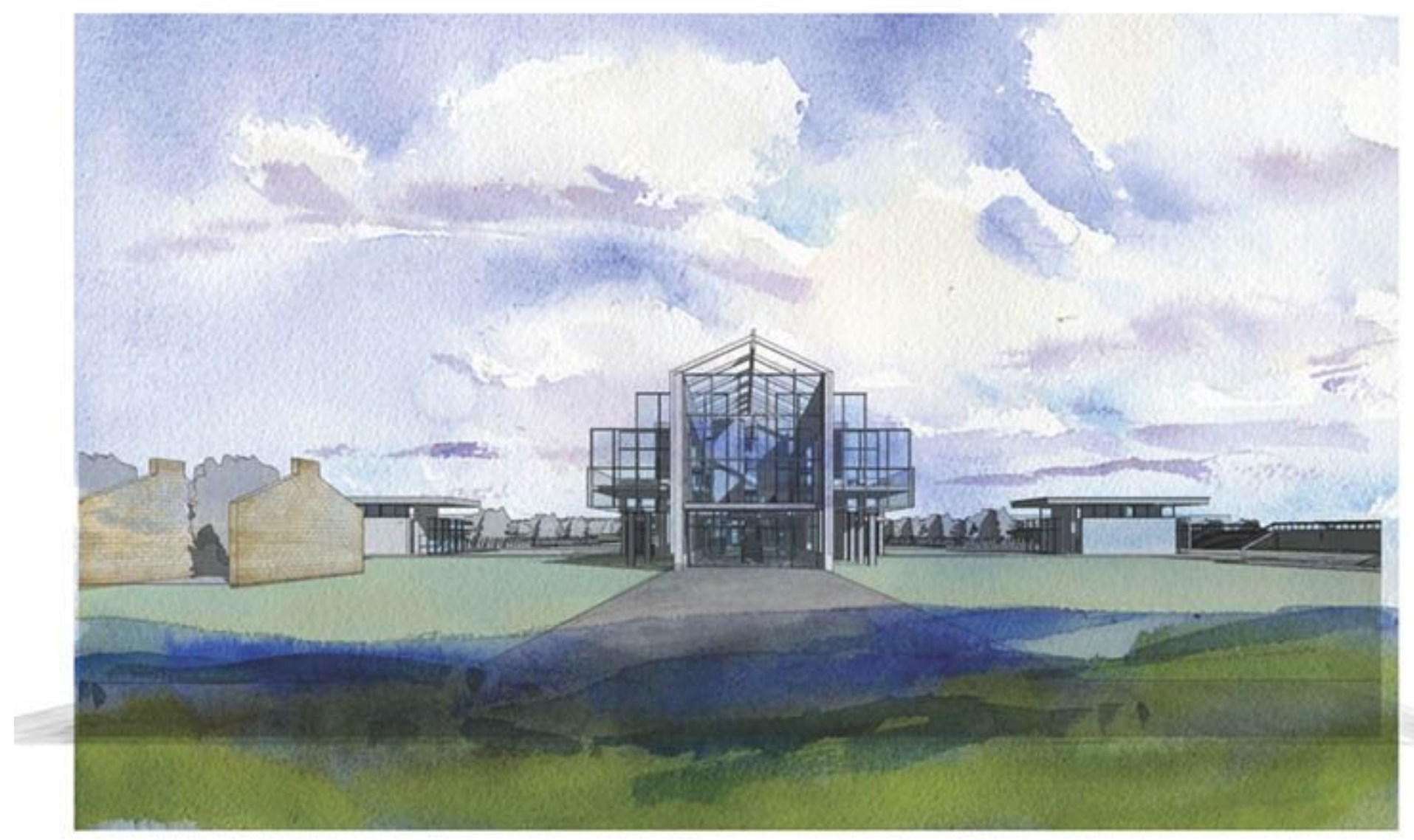

Figure 7: Exterior view of the entry at the primary market hall from King Street West, Kingston. 


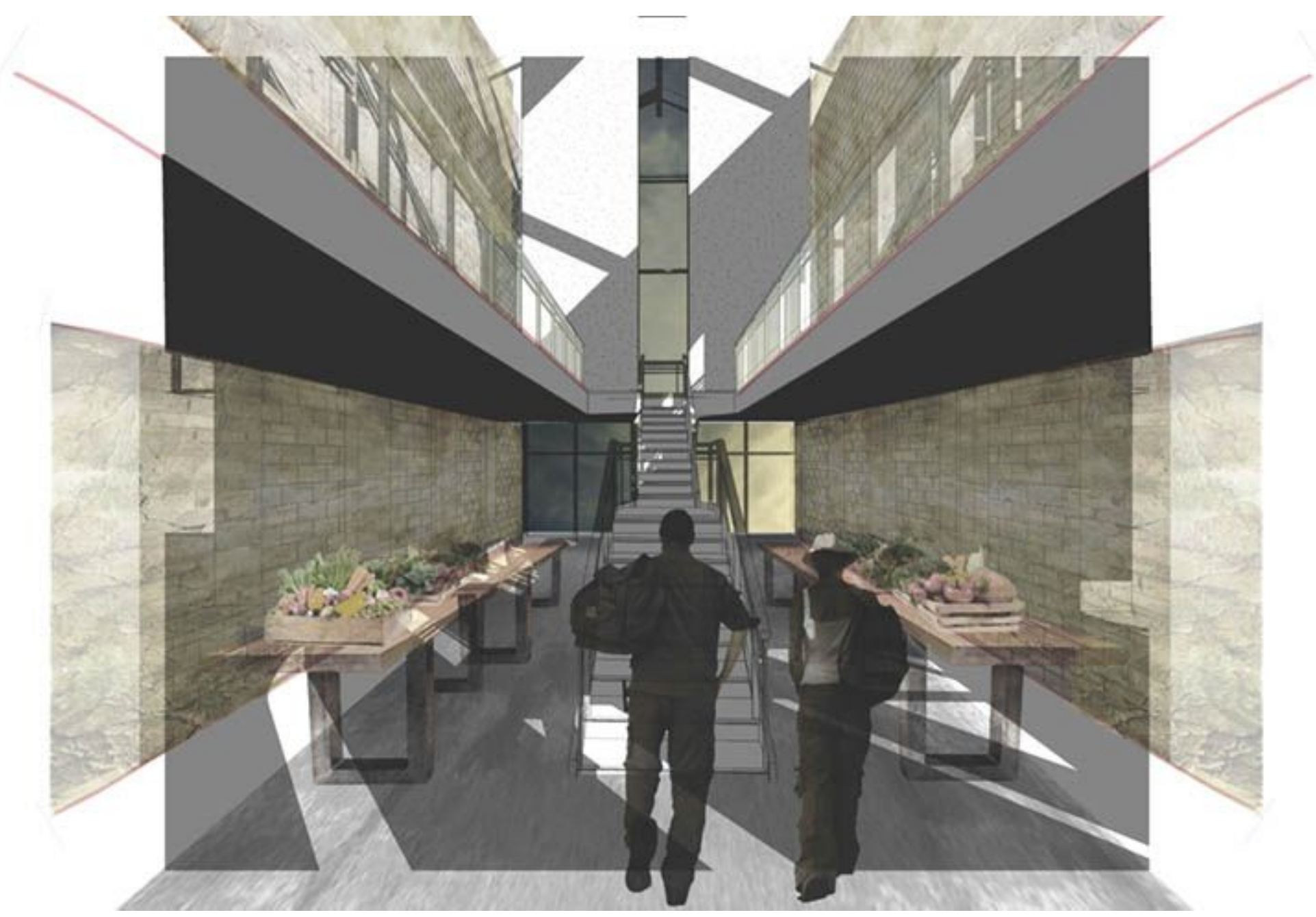

Figure 8: View of the entry in the primary market hall, located adjacent to the North walkway. The stairs leads to a second level, where there is additional space to sell food. 


\section{The Residence:}

\section{Walls Becoming Fragments:}

On the northern portion of the compound is the Residential Zone. As one enters this zone from the South, one can either check-in as a resident or register as a guest. Guest housing for conjugal visits and resident housing is located on the West side of this zone. What was formerly the 20 foot wall of confinement is now a facade that dresses the west portion of the guest and resident housing. Cuts and penetrations occur along this wall which allow for natural light to enter specific areas such as bedrooms and dining areas.

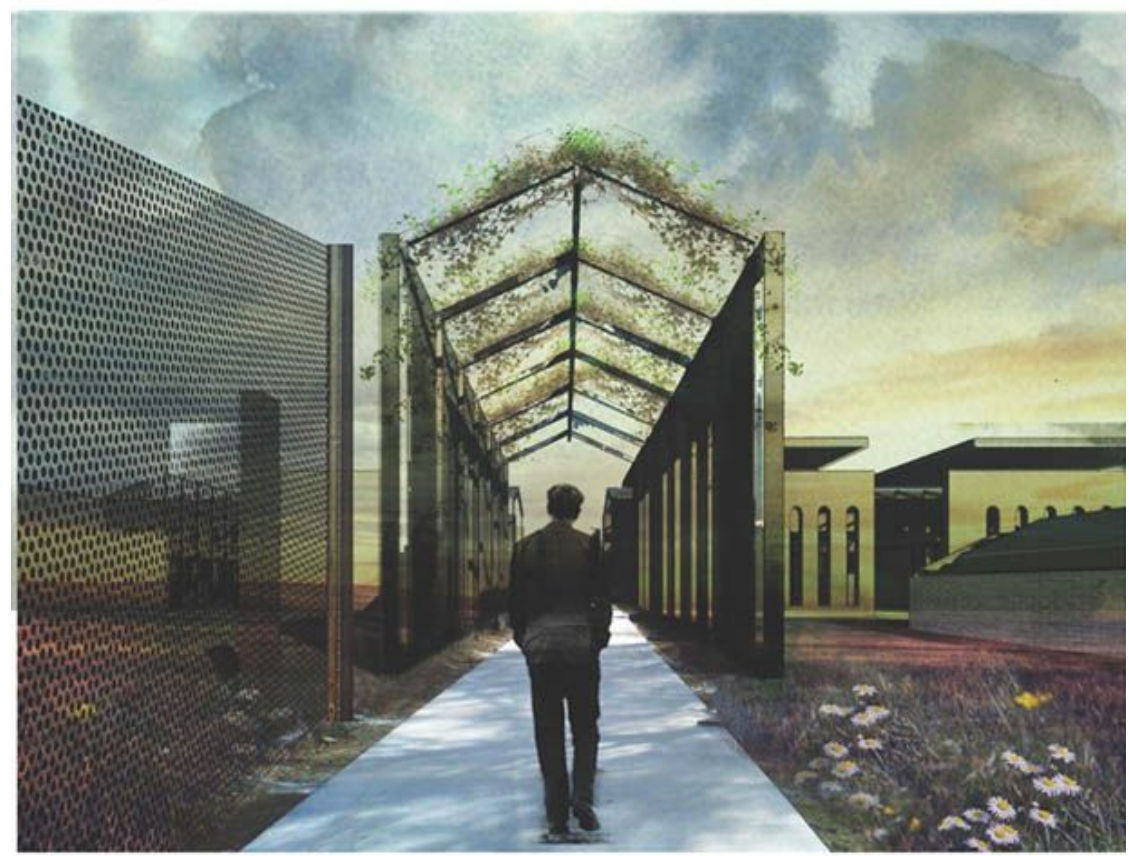

Figure 9: View of a walkway in the resident zone. The walkway consists of the old walls that used to encompass the workhouse. The roof and interior of the building have been removed. A truss system with steel columns hold the structure together. 


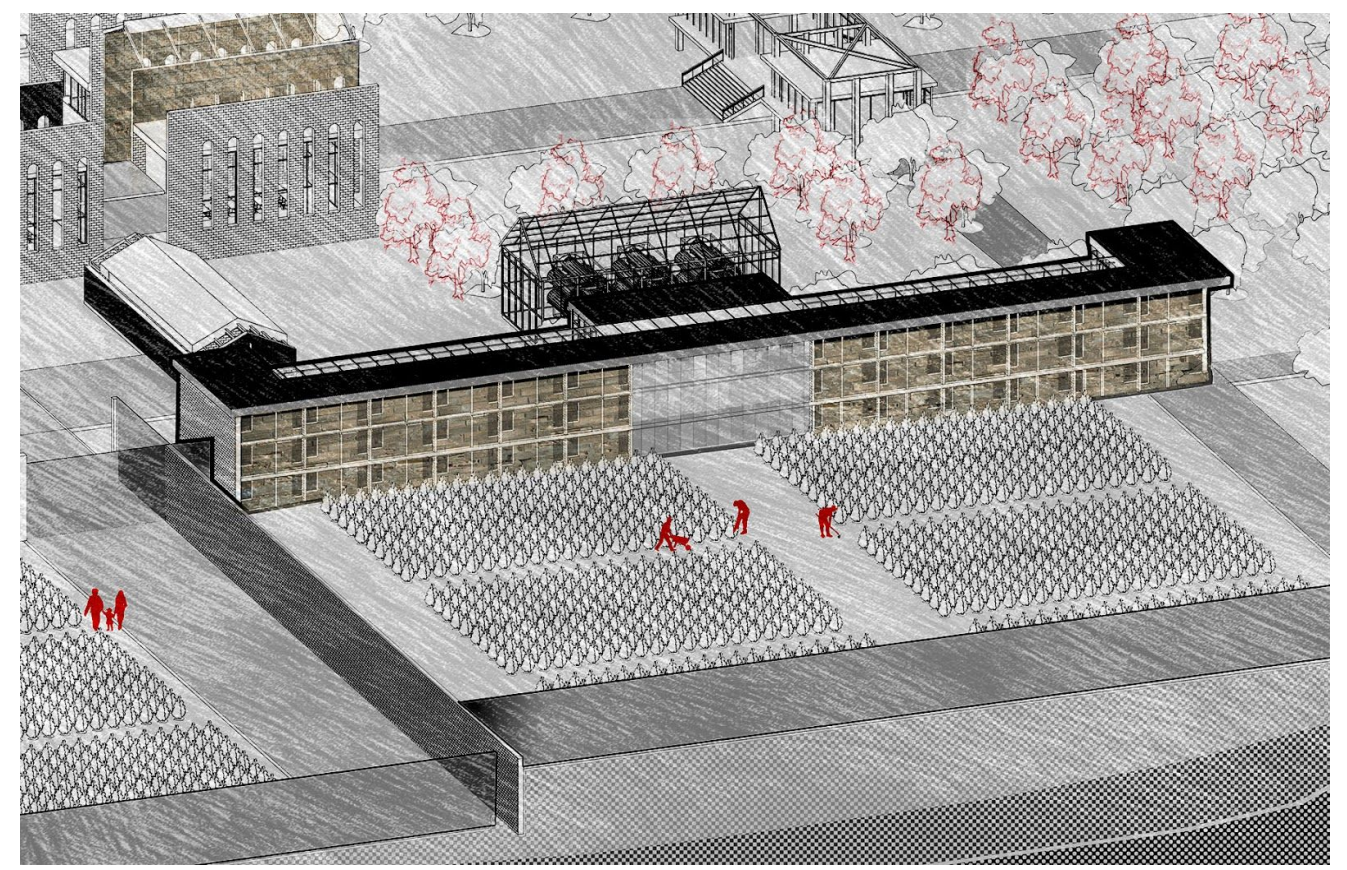

Figure 10: Axonometric view the west resident building. Residents tend to a vegetable garden that rests between the structure and Portsmouth Harbour. Stone texture in the view shows where the old walls are intact.

The buildings on the East side of this zone will also be united with the 20 foot wall that once constrained the site's former prisoners. Perforations within the existing East wall will also transform the original impenetrable wall. The building on northeast portion of this zone will house loading and storage areas where goods are held before they are brought to the Market Zone. Directly East are the educational and health centers. The healthcare and educational centers are intended to provide the residents with the resources they need in the rehabilitative process.

Located centrally in the Residential Zone are workhouses. Six of these workhouses are dedicated to the preparation of produce harvested from the gardens on the site, for market. The other two workhouses house woodworking and carpentry workshops. Similarly to the Market Hall, the East and West buildings, as well as the central core of the original building, have been extracted here. As a result, eight workhouses replace the original workhouse on the same location. The structural stability of these buildings is provided by portions of the original limestone walls. A curtain wall and new concrete wall assembly is inserted into the spaces between the old walls to fill the gaps created by removal of old building masses. 


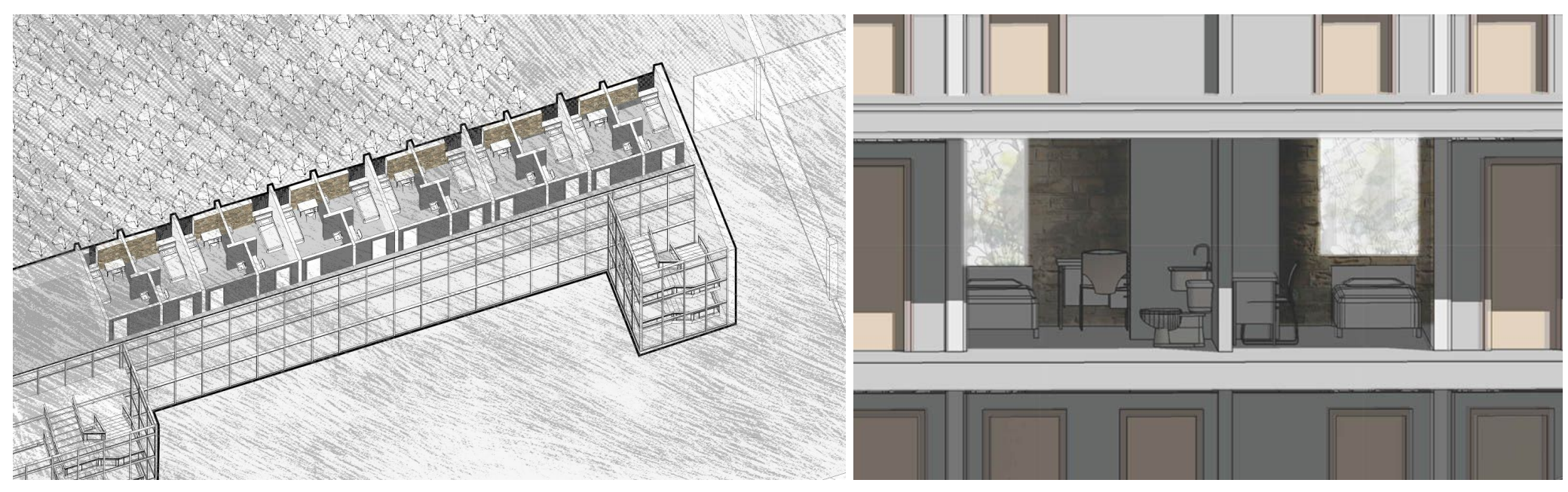

Figure 11 (Left): Axonometric aerial view the west resident building. Here, you can see the the residents rooms and their adjacency to the outside vegetable garden. A curtain wall glazing system covers the interior hallway that faces the courtyard inside the resident zone.

Figure 12 (Right): Elevation view of two resident rooms. Each room has a view to the exterior (either the Portsmouth Harbour or greenery), a study area, single bed, watercloset and sink. 


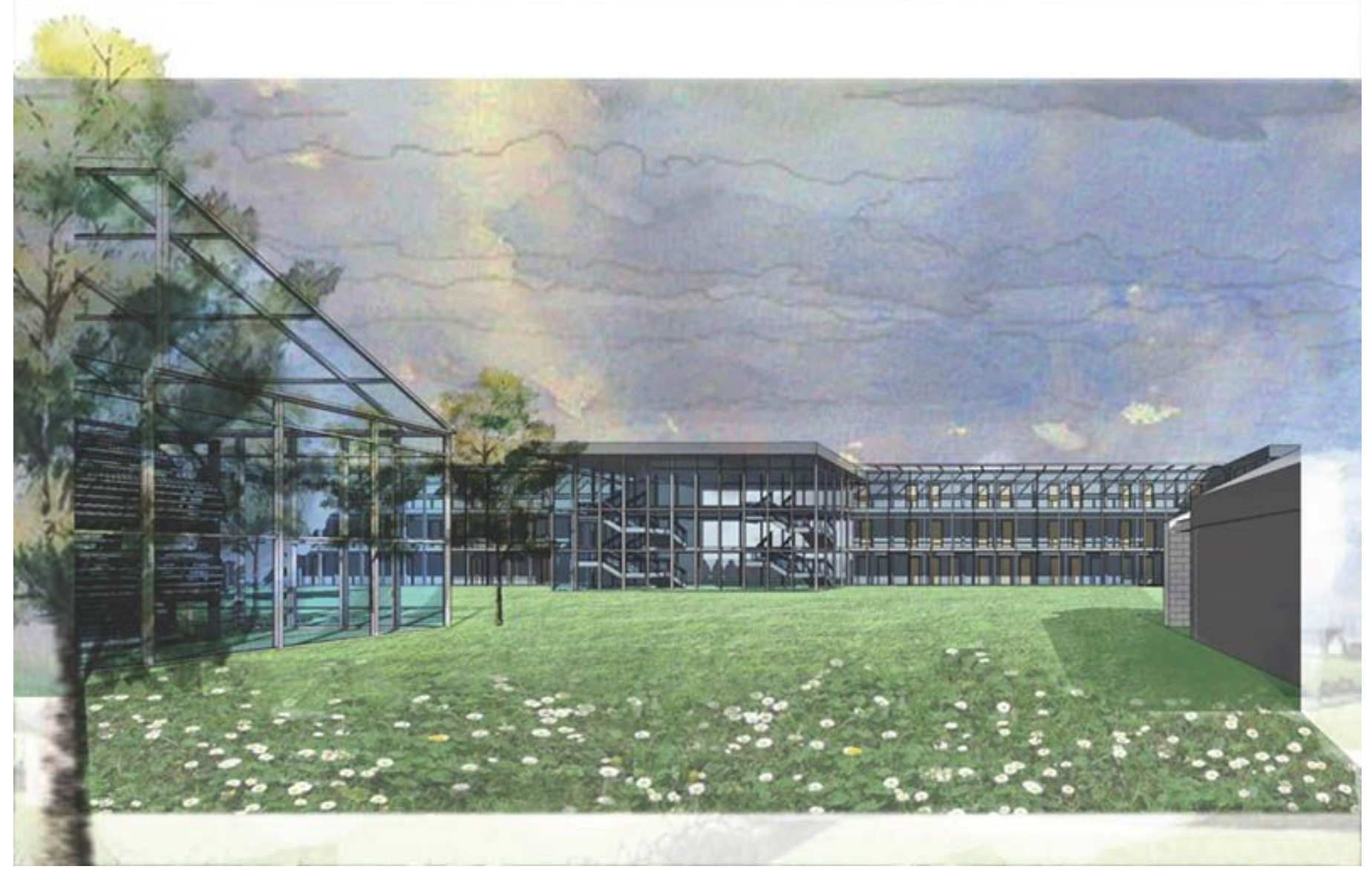

Figure 13: Exterior view of the West resident building from a greenhouse. The curtain wall that faces an internal courtyard and hallways with inmates rooms can be seen in this view. 


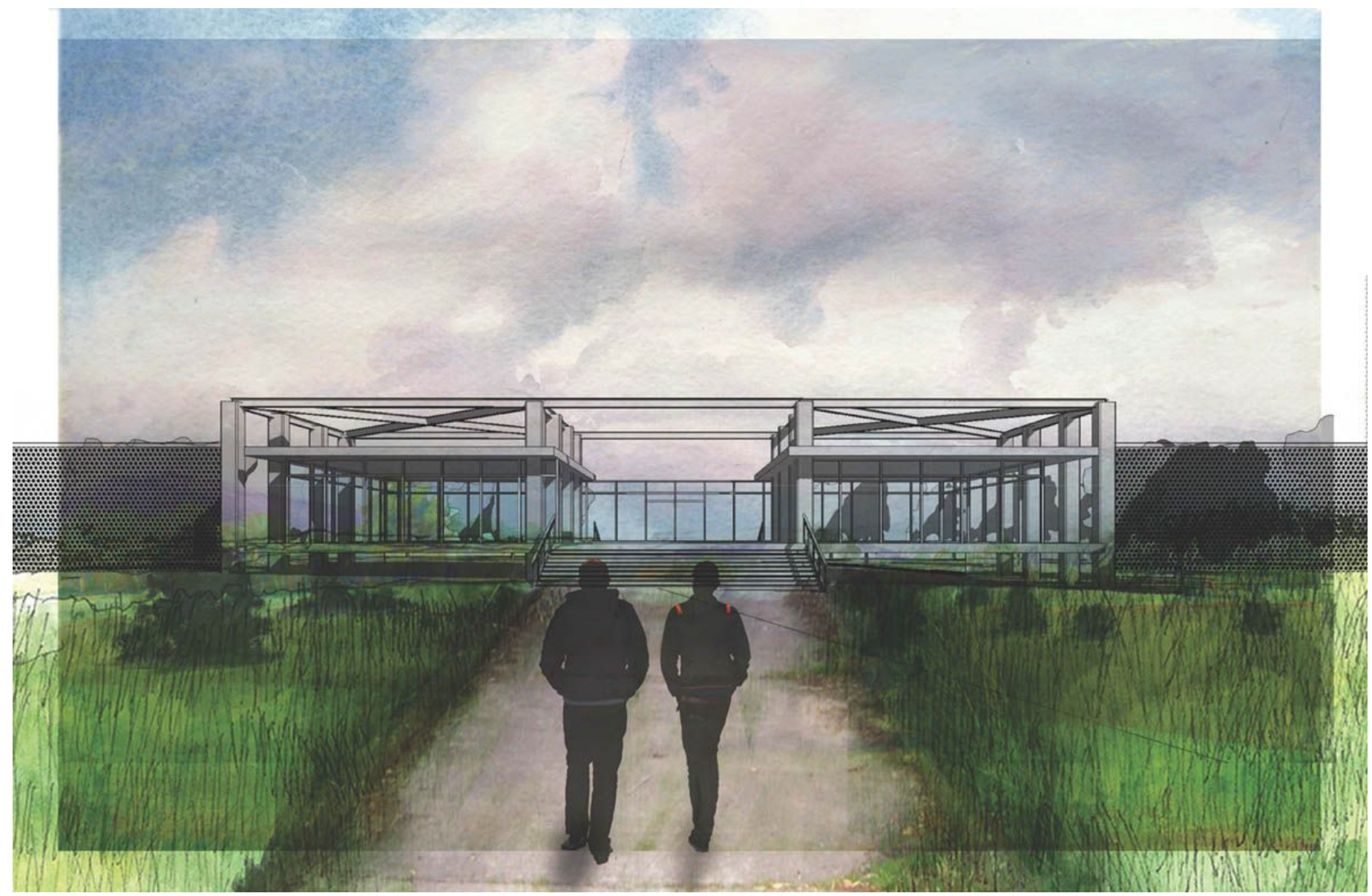

Figure 14: Exterior view of the South commons space. The commons space serves as a barrier between the main resident area and the resident gardening space adjacent to the St. Lawrence River. The resident common space is an area for inmates to socialize and participate in activities. 


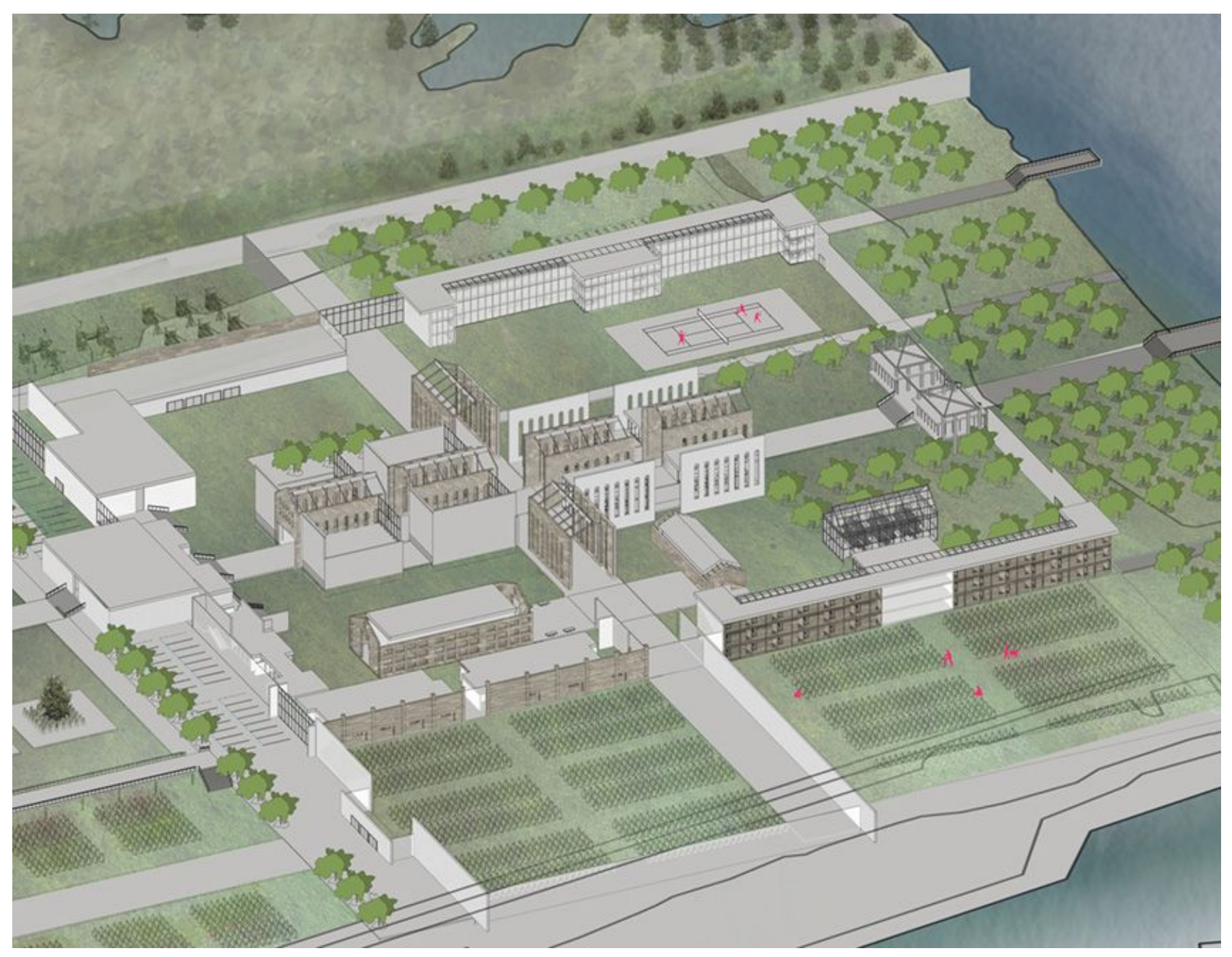

Figure 15: Axonometric view of the resident zone. View shows the housing and gardening areas along the perimeter. 


\section{CONCLUSION}

The Kingston Penitentiary currently sits on the edge the Saint Lawrence River, by the Portsmouth Olympic Harbour. It is a vacant vessel, a ghost that resides quietly on its land with a curious presence. If you walk by the building in the afternoon, you will notice the site's stillness. The winds from the Harbour are alive, but the building stays calm, as if an old soul at rest. Today, new potential programs for the site are currently being discussed, and the city of Kingston has invited the public to express their thoughts on the redevelopment of the site. ${ }^{62}$ "I can't wait to hear all the exciting possibilities presented by the community," says Mayor Bryan Paterson. "This is a significant community exercise to help shape the future of a gorgeous waterfront destination including a historic and storied prison and a marina that was the sailing venue for the 1976 Olympics." ${ }^{63}$ Canada Lands Company and the City of Kingston has retained the Toronto-based consortium, The Planning Partnership, to lead a "visioning" exercise, in collaboration with a team of experts in heritage planning, landscape architecture, architecture, urban design, coastal engineering and market and financial analysis, for the re-programming of Kingston Penitentiary. ${ }^{64}$ Ideas for the site are diverse, to say the least. Many proposals include the integration of a mixed-use development that would retain heritage structures such as the front gate, the main dome and the north cell block. There is also talk about the introduction of condominiums, the addition of a casino, an indoor tank so rowers could train in the off-season, or even thoughts of preserving the penitentiary as an "Alcatraz North." ${ }^{95}$ There is an abundance of ideas. This thesis takes the position that it is important to choose a direction that will not only bring life back into the site, but one that also serves to enlighten Canada's approach to correction and reform.

The application of the programme described in the thesis -- what would be most accurately described as an open prison farm -would be be highly appropriate for the site. The Liberal government, recognizing their benefits, is, in fact, now considering bringing back the prison farms that were shut down by the Conservatives in 2010. " "There's not a program in jail, even today,

62 "Wanted: ideas for the future of former Kingston Penitentiary and Portsmouth Olympic Harbour," May 31, 2016, accessed July 1, 2016, "https://www.cityofkingston.ca/-/wanted-ideas-for-the-future-of-former-kingston-penitentiary-and-portsmouth-olympic-harbour.

${ }^{63}$ Ibid.

${ }^{64}$ Ibid.

${ }^{65}$ Kathryn Blaze Baum, “Kingston Pen: Developers Dream up Next Chapter for Notorious Prison,” October 11, 2013, accessed July 14, 2016, http://www.theglobeandmail.com/news/national/kingston-pen-developers-dream-up-next-chapter-for-notorious-prison/article14850262/.

${ }^{66}$ Diana Mehta, “Trudeau Government Considers Reopening Prison Farms Shut down in 2010,” July 10, 2016, accessed July 13, 2016, http://www.theglobeandmail.com/news/national/trudeau-government-considers-reopening-prison-farms-shut-down-in-2010/article30844975/. 
that can teach those skills that the cows have taught me by working with them," says Pat Kincaid, who worked on a prison farm and has been out of prison for seven years. Kincaid credits the dairy cows on a now-shuttered prison farm in Ontario with teaching him the skills he needed to break a lifelong cycle of crime and incarceration. ${ }^{67}$

An open-prison farm with public areas would be beneficial for the site on many levels. First, it would invite the public into the site, reducing the "us versus them" mentality described by Justin Piché. The provision of local produce on the prison grounds would also help with Kingston's plan to become Canada's most sustainable city. ${ }^{68}$ Retaining the site as a prison is also in the spirit of heritage preservation, and a gesture of continuity with the site's history. This contrast between a past and present prison system can be a key factor in depicting "hopeful" advancements of our prison system. In this sense, the reformed Kingston Penitentiary can act as a prototype for future new prisons and reentry facilities. In fact, the reformation of Kingston Penitentiary here proposed can be read as a stepping stone towards a new model entirely: one where the prison is replaced by a re-entry facility. On this topic, it is interesting to point to the work of American architect Raphael Sperry, founder and president of Architects / Designers / Planners for Social Responsibility (ADPSR), which promotes alternatives to prisons, such as re-entry facilities and substance abuse treatment centres. ${ }^{69}$ It is time that Canada takes a step forward in the redevelopment of our prison system. Our current system -- a system whose recidivism rate is at a high of over fifty percent -- has resulted in an increasing numbers of inmates who

${ }^{67}$ Ibid.

68 "Sustainability," City of Kingston, 2016, accessed July 14, 2016, https://www.cityofkingston.ca/residents/environment-sustainability/sustainability.

${ }^{69}$ I here quote, with his permission, an email response from Raphael Sperry to my thesis advisor and myself: "It is our opinion that the problems posed by the criminal justice system in the United States today can't be solved by prison design. "Better" prisons will still enable, and even magnify, a deeply harmful and unjust system of mass incarceration. Until the fundamentals of racism, dehumanization, and promotion of violence are changed, and until real improvements are made to the communities across the US that are the most heavily victimized by both crime and by mass incarceration, police brutality, and other aspects of law enforcement. This is not to say that prison conditions have no bearing on the degree of justice within the nominal criminal justice system, but that we feel strongly that prison design is not capable of addressing the larger context. To take a couple of examples, the Van Cise-Simonet Detention Center in Denver won a number of AIA Design awards and is considered one of the most "humane" new jail designs in the country; it had been open less than a year before a homeless man was beaten to death in the booking area. Similarly, the California Health Facility (the largest prison hospital in the world, build pursuant to a court order), couldn't be fully utilized when it opened as the state failed to hire adequate staff and in fact didn't even provide adequate sanitary supplies like toilet paper. So even the best-intentioned prison designs often fail to change the basic lack of respect for humanity that is so pervasive in our justice system. ADPSR's more detailed essay about this is online: http://www.adpsr.org/home/prison_alternatives_initiative. The situation may be somewhat better in Canada -- I can't claim to have done as much research on Canada as the U.S. -- but I expect many of the principles are the same.

Regarding a closed prison in Ontario, I would suggest that many alternative programs would have a better social outcome than rehabilitating it into a low-security prison. Why not a community re-entry facility? Why not a rehabilitation center for people suffering from substance abuse or mental health issues? These are the kinds of places that would solve the root causes of crime in most communities. Every community's needs this way are different, hence ADPSR believes strongly that community engagement is a key portion of the design process for alternatives to incarceration. In terms of prison reuse projects, the YIMBY website would be helpful: http://www.yesinmybackyard.org/ Also http://www.growingchange.org/. Source: email to the Janine Debanné and Jessica Wright, May 6, 2016, with permission of the author..) 
are returning to prison for violent offences within five years of completing their sentences..$^{70}$ According to a report by the Globe and Mail, "55 per cent of prisoners in provincial and territorial jails are not behind bars because of a conviction," but because "they have been accused of a crime and are being held on remand." "Canada may not yet be ready to adopt the prison systems of Finland or Norway, but Corrections Canada has been, in recent years, open to considering some researched-based recommendations such as the elimination of solitary confinement. In an abstract by Tanya Rugge \& Terri-Lynne Scott: Restorative Justice's Impact on Participants' Psychological and Physical Health 2009-03, research on restorative justice has cited many positive benefits for participants. For example, restorative justice processes are satisfying to both victims and offenders Results indicated that the majority of participants did experience positive changes from pre-program to post-program. ${ }^{72}$ We need to consider progressive models when it comes to our Canadian prison systems. The welfare of our society depends on it. The argument for why we need prisons at all could also be considered. This thesis recognizes this fact, but outlines, here, a step on the path of advancement of our prisons. Through frictions and contrasts with our embedded assumptions regarding Kingston Penitentiary, the reformed prison -- situated inside and through the walls, and upon and through the ground traces, of the old Kingston Penitentiary -- new possibilities come to light. By "stepping" upon the old prison and "working out" a new prison within its old confines, this proposal aims to be a step in a more profound and healing approach to reformation of criminal offenders - and one that Canada might just be ready for.

${ }^{70}$ Catherine Latimer, "How We Created a Canadian Prison Crisis," Toronto Star, October 4, 2015, accessed July 1, 2016, https://www.thestar.com/opinion/commentary/2015/10/04/how-we-created-a-canadian-prison-crisis.html.

71 “Most of Canada's Prisoners Have Never Been Convicted of Anything. Why Are They in Jail?," The Globe and Mail, July 17, 2015, accessed July 14, 2016, http://www.theglobeandmail.com/opinion/editorials/most-of-canadas-prisoners-have-never-been-convicted-of-anything-why-are-they-in-jail/article25559599

${ }^{72}$ Tanya Rugge and Terri-Lynne Scott, “Restorative Justice's Impact on Participants' Psychological and Physical Health,” Public Safety Canada, November 2009, accessed June 02, 2016, http://www.publicsafety.gc.ca/cnt/rsrcs/pblctns/2009-03-rjp/2009-03-rjp-eng.pdf. 


\section{POSTSCRIPT}

\section{Rethinking the programme as a post-prison culture}

The focus of this thesis has been to reinvent Kingston Penitentiary as an open prison, reimagining it as a building that allows the prisoners and public to interact on a semi-controlled basis. One consideration to make, however, is how the interaction between the prisoners and the public could be further merged. Could a renewed Kingston Penitentiary have no barriers at all? Is it possible for this place to exist without formal obstacles between the prisoners and the public? Could the former Kingston Penitentiary become a place where Kingston's culture could thrive alongside the existence of prisoners -- a site of public gatherings and festivals, even?

To create such a place, all boundaries between the prison grounds and market would need to be removed, and the prison grounds would need to be conceived as entirely public. In this alternate design, the prisoners and public would coexist in all of the spaces on the site except in the residential quarters. These would be conceived as dormitory or apartment complexes, where the prisoners could retreat and find privacy after a long day, just as people who live outside of the prison. The residence could be built against the old bounding walls of the Kingston Penitentiary grounds, as originally described in the thesis. Public gathering spaces could, however, be woven into the scheme like a web, allowing for community events to take place throughout the site. Nodes near the water's edge along the Portsmouth Harbour would be especially attractive. During quiet times, the public and prisoners alike could meander through these spaces, to find a place to sit, pic-nic, or have a small gathering. During thriving times such as when a festival takes over the city, the prison grounds would provide a useful venue. On those occasions, Kingston Penitentiary becomes a poignant backdrop seen on the horizon of festivals and ceremonies.

The location of the Kingston Penitentiary grounds is adjacent to the Portsmouth Harbour where the sailing events of the 1976 Montreal Olympics took place. This is a prime location, having an abundant body of water and land with close proximity to the downtown core of Kingston. The site is close to residential areas and approximately a kilometer away from Princess Street, the main shopping district in Kingston. Bringing the public into such a prime location with an abundant historical background could further educate the public on the site's history and importance, and more importantly in relation to the thesis, promote a better understanding of prison culture. 
Due to the past connection to the 1976 Olympics and to Kingston's ideal sailing conditions, a large sailing community has flourished in the city. In 1969, a group of enthusiastic sailors decided to establish CORK to host international sailing events off Kingston. ${ }^{73}$ The area offers some of the best fresh-water sailing in the world, excellent wind and wave conditions, and is a short distance from shore to the race courses. Leading up to the 1976 Olympics, the CORK regatta offered excellent training for sailors, coaches and officials, and has since become a fixture on the international calendar. ${ }^{74}$ Since 2000 alone, CORK has hosted dozens of North American and World Championships out of Portsmouth Olympic Harbour. Highlights include the 2007 ISAF Youth World Sailing Championships and the 2010 Optimist North American. ${ }^{75}$ The site of the Kingston Penitentiary could be a potential site for future CORK events, as there a vast amount of space for festivities which could house hundreds, if not several thousands, of athletes and spectators.

Another big event in Kingston is "Shop after Dark" which takes place during the Christmas holiday season. During this event, which is complete with tasty food and festive beverages, carolers and pedestrians fill the streets, and local shops open their doors to the public until $10 \mathrm{pm}$. The public can stroll along Princess Street looking for great finds and perhaps enjoy a little treasure discovered while window-shopping. For the purpose of the thesis, this event could extend to the Kingston Penitentiary site, and local vendors could set up stalls with handicrafts and holiday foods (grown and prepared by the prisoners). The water by the Portsmouth Harbour could be sectioned off and a skating rink could be made where people could further enjoy the atmosphere of the festivities. "Feb Fest" is likewise a winter celebration that occurs in the winter months of the city. The activities that go on during "Feb Fest" -- including figure skating, hockey games and the art of making ice sculptures -- could also benefit from the waterfront at the Portsmouth Harbour. Lastly, music events such as "Limestone City Blues Festival" and "Pop-Up Country Kingston," could have smaller shows during the day at the site. The Kingston Penitentiary location could be the destination hub for smaller performances and emerging artists to showcase their musical talents. Bringing the central hub of Kingston further, beyond Princess Street, would promote a sense of community and civic culture.

Kingston Penitentiary's 8.6 hectares offers tremendous potential, especially when they are allowed to become connected to Portsmouth Harbour. Not unlike Lebreton Flats in Ottawa, which expands over 84 hectares, Kingston Penitentiary could become a dynamic locum of activity and life after so many years of concealment behind a tall concrete wall. Like Lebreton Flats is to

\footnotetext{
73 "About CORK," CORK, accessed August 30, 2016. http://www.cork.org/cork/.

${ }^{74}$ Ibid.

${ }^{75}$ Ibid.
} 
Ottawa's downtown, Kingston Penitentiary exists in close proximity to the downtown of Kingston, while not being completely central. Lebreton Flats accommodates large city events like the Ottawa City Bluesfest. It is also adjacent to vital city buildings such as the Canadian War museum, is becoming tied to a transportation hub and crop of condo towers, and may also become the home of the city's hockey stadium. Similarly, Kingston Penitentiary could take on the role of catalyst in Kingston's evolution. The former prison grounds could emulate residential and cultural sites such as Lebreton in Ottawa, but in a yet more interesting and hopeful manner, in that prisoners would also be part of the landscape. Rather than a "regular public" inhabiting the condo towers of a pleasant consumer cultural landscape, inmates serving minimal sentences would inhabit the residential component of this development. A public thoroughfare running through the old prison grounds would be the starting point of a much farther reaching project of reconciliation of the prison and its population with the town of Kingston. Such a vision and strategy would bring further life (and livelihood) into the site of the Kingston Penitentiary, and this, on a grander scale: one that involves the whole city. 
APPENDIX A Architectural Programme for Reforming Kingston Penitentiary

\section{Zone Specifics and Programme:}

The market: Public

Entry Hall: 4,400 Sq. Ft.

Primary hall for public to enter and buy goods produced in residence zone. Contains two Lifts to upper mezzanines. Provides space for tables to showcase produce.

\section{Secondary Halls: 4,600 Sq. Ft. x 2}

Secondary halls for public to enter and buy goods produced in residence zone. Contains two Lifts to upper mezzanines.

\section{Loading Hall: 6,000 Sq. Ft.}

Loading Hall for storage of goods brought from the residence zone. Provides shaded and refrigerated areas for food. Loading dock for transportation is located on the South side of this building.

\section{Outdoor Restroom Pavilions: 1,500 Sq. Ft. x 2}

Two pavilions will be provided for the public use, both will have a women's and men's restroom, both with accessible accommodations.

\section{Outdoor Playground: 5,000 Sq. Ft.}

This zone will be located adjacent to the Entry Hall. It will provide children with a splash pad and play structures.

\section{Exterior Walkway/Circulation: 30,780 Sq. Ft.}

These zones provide the occupants a space to be utilized when transitioning from the various public spaces.

Public Gardens: 120,340 Sq. Ft.

There are two gardens available for the public to use; one that is ornamental and one for berry picking.

\section{Programme: The residence: Private}


Administration Hall: 6,000 Sq. Ft.

The administration hall is where residents check in during their arrival.

Loading Area: 7,500 Sq. Ft.

The loading area is for the housing of play structures and storage of equipment.

Daycare: 2,300 Sq. Ft.

The daycare is adjacent to the conjugal housing where the children of the residents can play during their stay.

\section{Conjugal Housing: 580 Sq. Ft. x 6}

This housing is provided for the family members of the residents who visit the site.

\section{Resident Housing: 6580 Sq. Ft. $x 2$}

This housing is provided for the residents. Each room has a water closet, sink, desk and bed.

\section{Shower House: 2070 Sq. Ft.}

An external building where tenants of the site can shower.

\section{Health Center: 2,800 Sq. Ft.}

In this building, the residents can receive dental, medical and mental health care.

\section{Educational Center: 6,500 Sq. Ft.}

This building provides classrooms for the residents where they can take classes and vocational training.

\section{Outdoor Lodges: 1,170 Sq. Ft. x 2}

These areas are where the residents can socialize during their recreational time.

\section{Orchard: 240,860 Sq. Ft.}

This land is where produce is cultivated for the prisoner and customers of the south market.

\section{Recreational Area: 352,60 Sq. Ft.}

The recreational area is a space where inmates can partake in physical and social activities.

Indoor Workhouse/Greenhouse: 1,000 Sq. Ft.

In this building, vermicular composting and indoor planting take place.

\section{Workhouses: 6,200 Sq. Ft.}

In these workhouses, the 
Dining Halls: 6,200 Sq. Ft. 
APPENDIX B Images of fabrication related to the Kingston Penitentiary
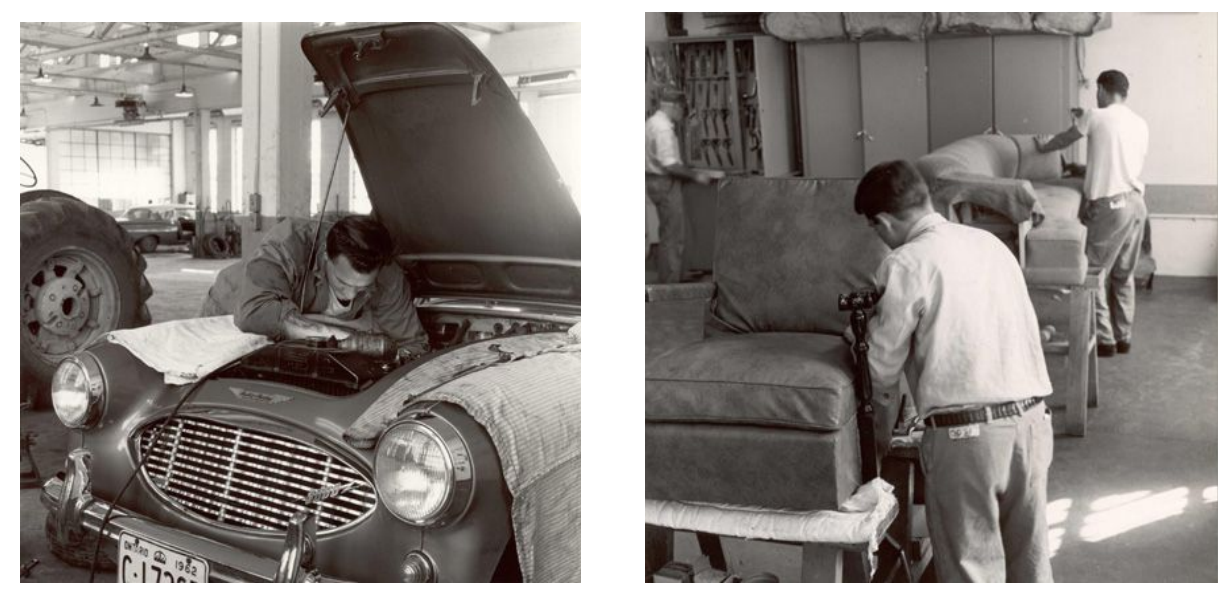

Figure 16 (Top Left): Kingston Penitentiary Mechanical Garage, 1962. Figure 17 (Top Right): Kingston Penitentiary Upholstery, 1962.
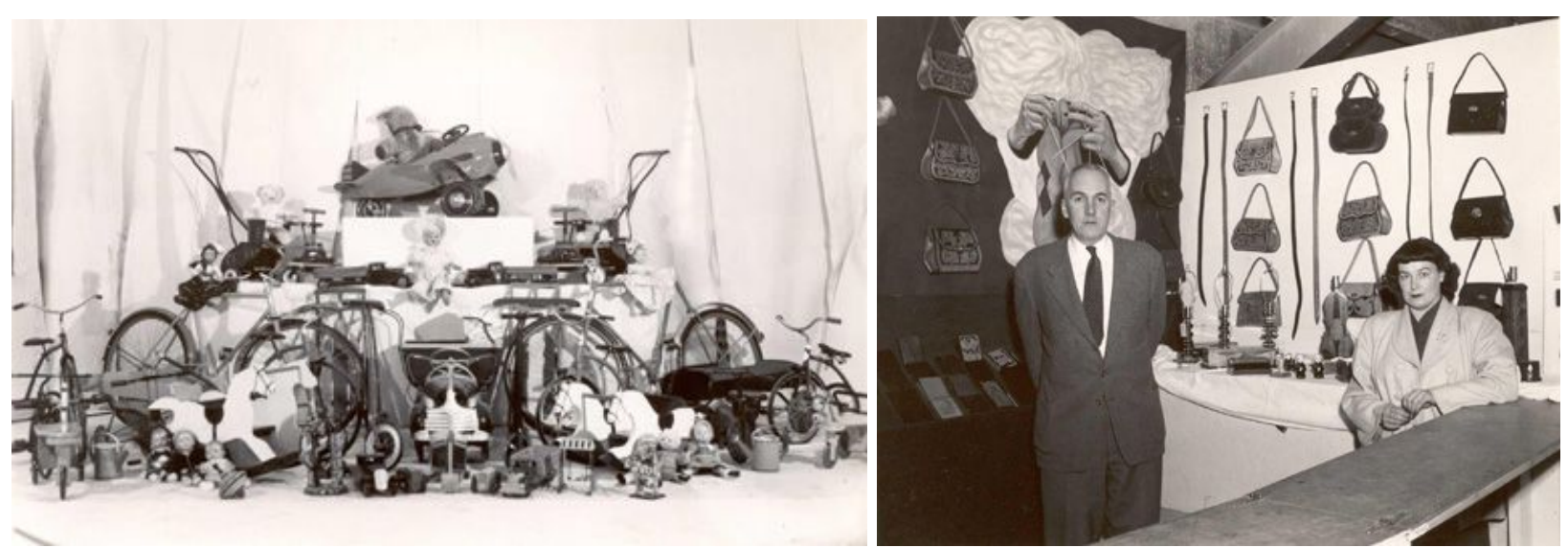

Figure 18 (Left Right): Refurbished Toys for the Needy, by Kingston Penitentiary Inmates, c1950s. Figure 19 (Bottom Right): Kingston Penitentiary Inmate Hobbycraft Sale, Kingston Exhibition, 1952. 

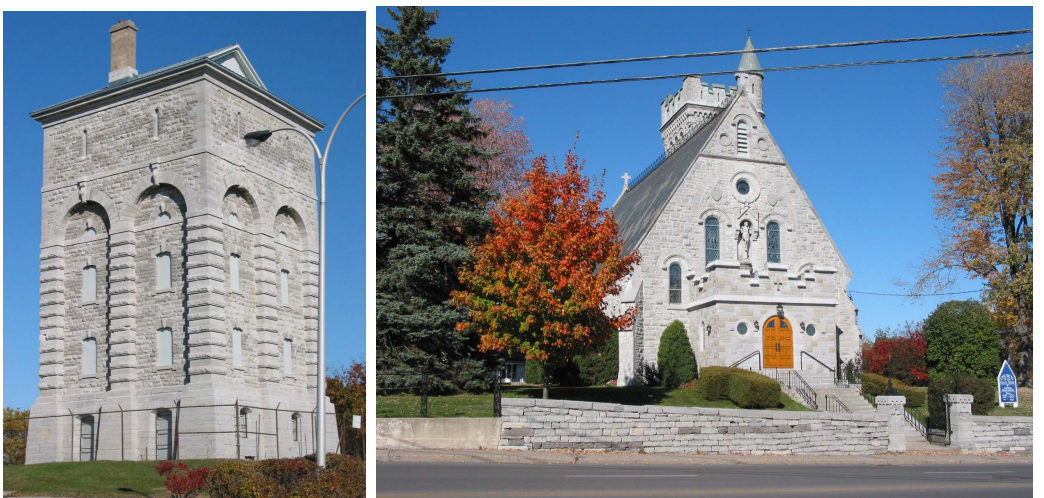

Figure 20 (Top Left): This water tower was originally part of the penitentiary farm. Construction was carried out by inmates and was completed in 1895. The stones were quarried and cut by inmates.

Figure 21 (Top Right): "The Church of the Good Thief", it was constructed from limestone quarried, cut and transported to the site by convict gangs from the Kingston Penitentiary. The church was built between 1892 and 1894, and designed to include a mixture of Neo-Gothic and Romanesque architectural styles.
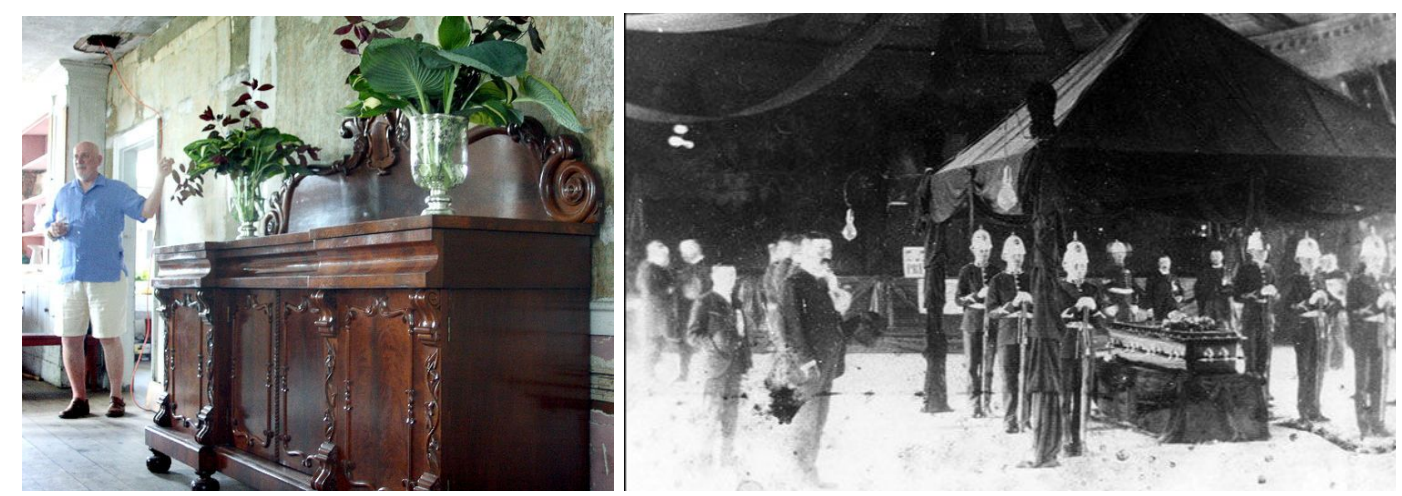

Figure 22 (Bottom Left): This buffet table was donated by Nancy Wright to the Stratford Perth Heritage Foundation for Fryfogel Tavern. It was made by inmates at the Kingston Penitentiary in the 1800 s.

Figure 23 (Bottom Right): Sir John A. Macdonald died in June, 1891, his coffin rested on a large wooden table in Kingston City Hall, a table made in the prison's furniture shop. 
F.

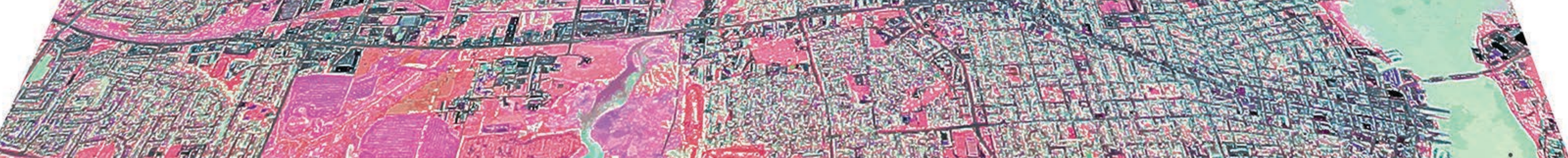

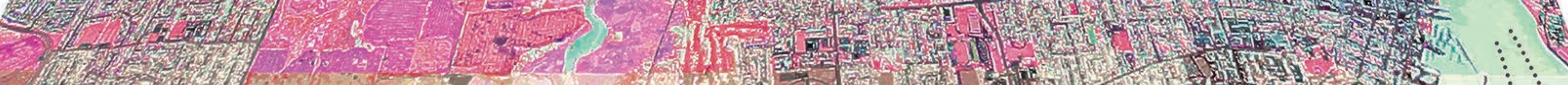
$\vdots 270$ (5) 2. (o)
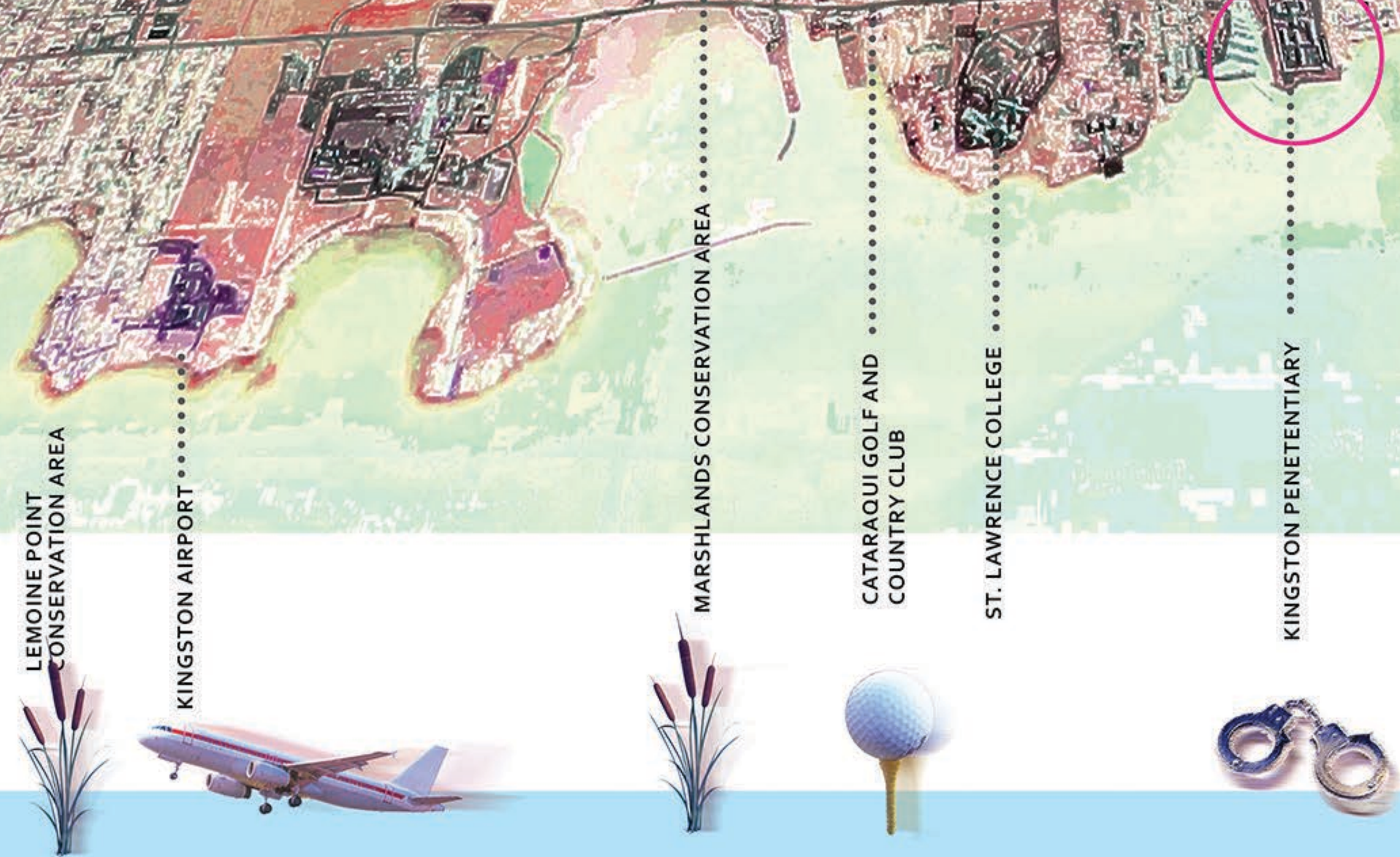
किजe Hountwis of

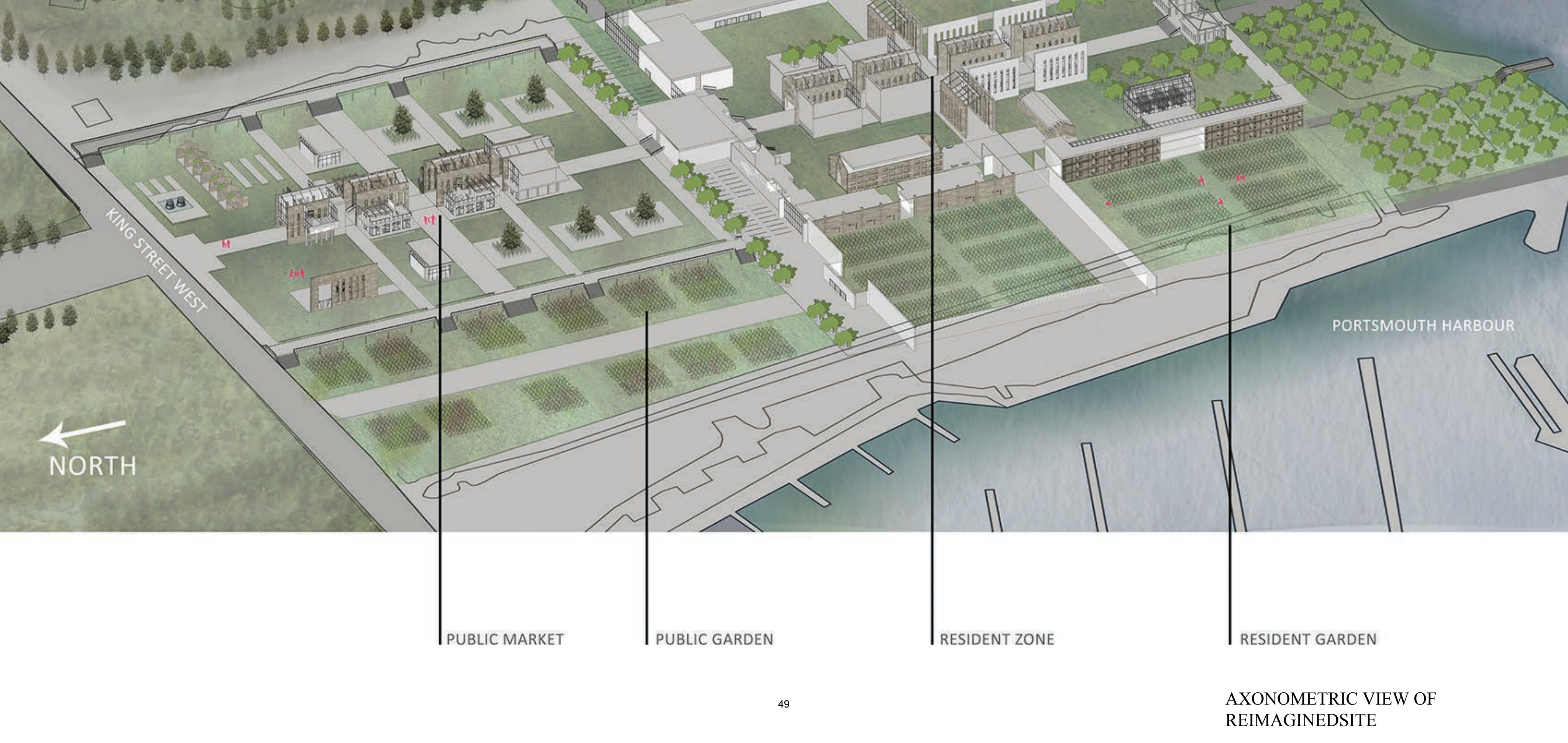




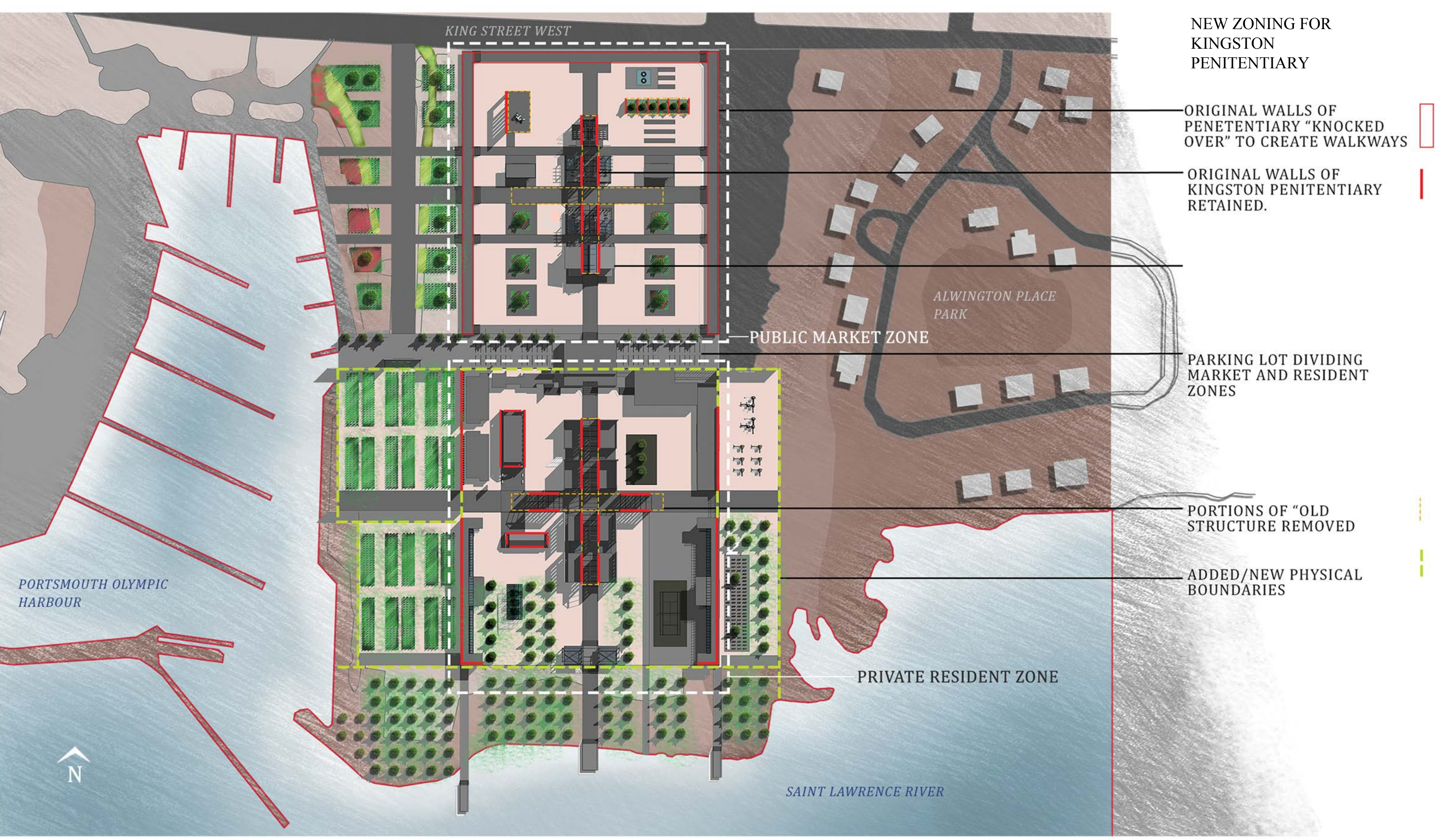


NEW BUILDING PLAN FOR KINGSTON PENITENTIARY

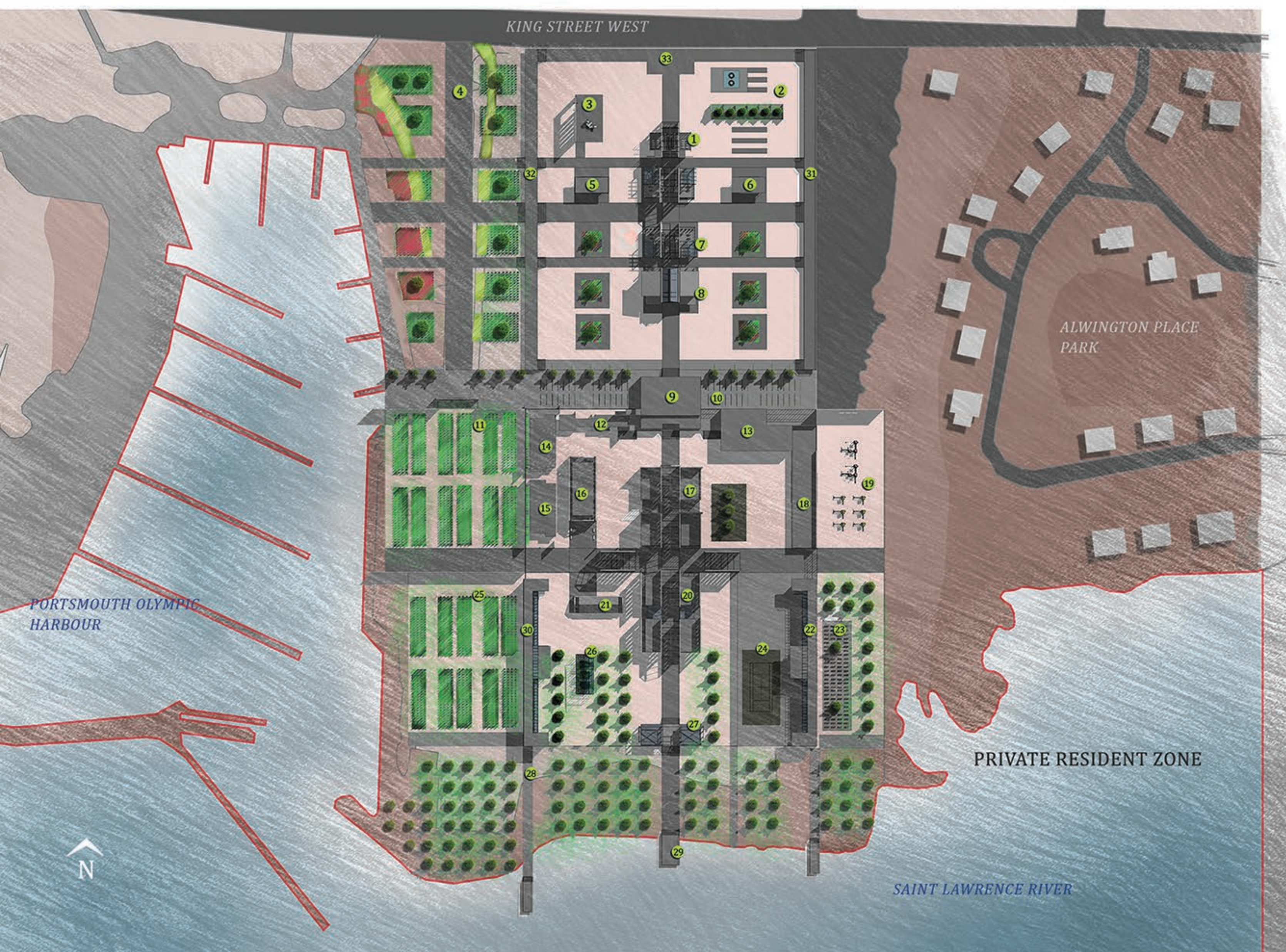

1. ENTRY HALL TO THE MARKET

2.FOUNTANA AT ENTRY OF SITE-ORIGINALSITE
OF FAMILY HOUSING, NOW AGARDENEATURE 3. PLAY AREA-WITH PLAY-STRUCTUREAND SWING SET ATTACHED TO WEST WALL OF THE
OLD ADMINISTRATION BUILDING 4. PUBLIC ORNAMENTAL GARDEN

5\& 6. PUBLIC RESTROOMS

7. PUBLIC MARKET AND EATING BUILDINGS

8. LOADING ZONE AND STORAGE AREA FOR

MARKET

9. ADMINISTRATION BUILDING

10. PARKING LOT

11. PUBLIC FIELD FOR BERRY PICKING

12. DAYCARE FOR THE VISITING CHILDREN OF

THE RESIDENTS

13. EDUCATIONAL AND VOCATIONAL TRAINING
BUILDING.

$14 \& 15$. FAMIIY VISIT HOUSING

16. HEALTHCARE BUILDING

17. WORKHOUSES

18. LOADING ZONES AND MAKER SPACES

19. ZONE FOR PLAY STRUCTURES (GIVEN TO THE 20. DINING HALLS AND KITCHENS

21. SHOWER BUILDING

22/30. RESIDENT BUILDINGS

23. OUTDOOR ORCHARD AND PLANTERS

24. RECREATIONAL ZONE

25. VEGETABLE GARDEN FOR RESIDENTS

26. GREEN HOUSE FOR HORIZONTAL PLANTING

27. SOCIAL LODGES

28. RESIDENT ORCHARD

29. DOCK FOR GUARDS

31 \&32. BOARDWALKS RAISED 10 FEET WITH

KING STREET WEST TO PARKING LOT

33. WALKWAY AT ENTRY OF SITE, LEVEL WITH GROUND PLANE-METAPHORICALLY REP-
RESENTS OLD WALL BEING "KNOCKED DOWN" 


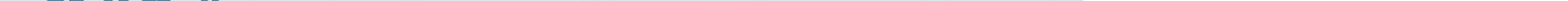





\section{BIBLIOGRAPHY}

"About CORK." CORK. Accessed August 30, 2016. http://www.cork.org/cork/.

Adams, William Lee. “Norway Builds the World's Most Humane Prison.” Time. October 5, 2010, accessed May $12,2016$.

http://content.time.com/time/magazine/article/0,9171,1986002,00.html.

Bentham, Jeremy and Miran Božovič. The Panopticon Writings. New York: Verso Books, 1995.

Bichell, Rae Ellen. "In Finland's 'open Prisons,' Inmates Have the Keys." Public Radio International. April 15, 2015, accessed July 01, 2016. http://www.pri.org/stories/2015-04-15/finlands-open-prisons-inmates-have-keys.

Blaze Baum, Kathryn. “Kingston Pen: Developers Dream up Next Chapter for Notorious Prison.” October 11, 2013, accessed July 14, 2016.

http://www.theglobeandmail.com/news/national/kingston-pen-developers-dream-up-next-chapter-for-notorious-prison/article14850262/.

"Brazil Prisoners Reading Books to Shorten Their Sentences." The Telegraph. June 26, 2012, accessed May 11, 2016.

http://www.telegraph.co.uk/news/worldnews/southamerica/brazil/9356129/Brazil-prisoners-reading-books-to-shorten-their-sentences.html.

Brooks, David. “The Prison Problem,” The New York Times.” September 29, 2015, accessed June 25, 2016.

http://www.nytimes.com/2015/09/29/opinion/david-brooks-the-prison-problem.html?_r=0.

Cameron, Stevie. "Kingston Penitentiary: Canada's Most Famous Prison Closes Its Doors." The Globe and Mail. September 29, 2013, accessed May 10, 2016. http://www.theglobeandmail.com/news/national/kingston-penitentiary-closes-its-doors-as-canadas-most-famous-prison/article14598900/?page=all.

Camp, Scott D., Gerald G. Gaes and Julianne B. Nelson. Measuring Prison Performance: Government Privatization and Accountability. United States: AltaMira Press, U.S., 2004.

“Canada's New Government Has a Lot of Work to Do, Says Federal Watchdog," CBC News. November 17, 2015, accessed June 12, 2016.

http://www.cbc.ca/news/canada/british-columbia/prison-watchdog-ongoing-problems-jail-1.3321819.

“Carlo Scarpa - A Profile." Directed by Murray Grigor and Egle Trincanato. Italy, 1996. Accessed April 02, 2016.

https://www.youtube.com/watch?v=9KxXgkEWK1U.

Chammah, Maurice. "The 17-Year-Old Adult." The Marshall Project. March 6, 2015, accessed June 07, 2016. https://www.themarshallproject.org/2015/03/03/the-17-year-old-adults\#.KNeIRckZe.

Chessell, Bruce. "A Match Made in Heaven." Stratford Beacon Herald. June 30, 2014, accessed June 11, 2016.

http://www.stratfordbeaconherald.com/2014/06/30/historic-fryfogel-tavern-gets-generous-donation-of-antique-furniture.

Dawson, Tyler. "By the Numbers: Key Findings from the Innes Jail Task Force." The Ottawa Citizen, June 01, 2016, accessed June $05,2016$.

http://ottawacitizen.com/news/local-news/by-the-numbers-key-findings-from-the-innes-jail-task-force.

Dilulio, John et al. Performance Measures for the Criminal Justice System. Princeton, New Jersey: Bureau of Justice Statistics , Princeton University, October 
Essert, Matt. “Norway Treats Its Inmates Like People - the Result Is a System America Can Only Dream of." Mic. February 5, 2014 , accessed May 10, 2016. https://mic.com/articles/81233/norway-treats-its-inmates-like-people-the-result-is-a-system-america-can-only-dream-of\#.F3Mk5iQaU.

Foucault, Michel. Discipline and Punish: The Birth of the Prison. New York: Vintage Books, 1975.

Gentleman, Amelia. "Inside Halden, the Most Humane Prison in the World." The Guardian. May 22, 2012, accessed April $15,2016$. https://www.theguardian.com/society/2012/may/18/halden-most-humane-prison-in-world.

"Health, Hunger, and Hope." Growing Change. February 6, 2015, accessed July 14, 2016.

http://www.growingchange.org/reclaim-attain-sustain/health-hunger-hope/.

Hsu, Ted. "Kingston Penitentiary to Close Its Doors after 178 Years." Ted Hsu. September 27, 2013, accessed May 10, 2016.

http://blog.tedhsu.ca/2013/09/27/kingston-penitentiary-to-close-its-doors-after-178-years/.

Johnson, Dana. “Federal Heritage Building Review Office.” Accessed May 14, 2016.

file://C:/Users/USER/Downloads/1989-032(F)\%20Kingston\%20Penitentiary\%20Buildings\%200N_0CRed\%20(10).pdf.

Johnson, Dave. "Historical Overview of Kingston Penitentiary." United Way Kingston. Accessed May 01, 2016,

http://www.unitedwaykfla.ca/wp-content/uploads/2013/09/KP-history-from-Dave-Johnston.pdf.

Judge, Phoebe. "NC Has Closed Nine Correctional Facilities Recently, Here's Why." WUNC. July 22, 2014, accessed July $02,2016$. http://wunc.org/post/nc-has-closed-nine-correctional-facilities-recently-heres-why\#stream/0.

Kingston Penitentiary. Self-guided tour. Kingston, Ontario, May 21, 2016.

Larson, Doran. "Why Scandinavian Prisons Are Superior," The Atlantic. September 24, 2013, accessed May 10, 2016 http://www.theatlantic.com/international/archive/2013/09/why-scandinavian-prisons-are-superior/279949/.

Latimer, Catherine. "How We Created a Canadian Prison Crisis." Toronto Star. October 4, 2015, accessed July 1, 2016. https://www.thestar.com/opinion/commentary/2015/10/04/how-we-created-a-canadian-prison-crisis.html.

"Kingston Penitentiary National Historic Site of Canada." Historic Places." Accessed June 11, 2016.

http://www.historicplaces.ca/en/rep-reg/place-lieu.aspx?id=13265.

Mallgrave, Harry Francis. Modern Architectural Theory: A Historical Survey, 1673-1968. United Kingdom: Cambridge University Press, 2009.

Mallinder, Lorraine. "Norway's Prison Without Bars: 'It's a trust thing." Al Jazeera Media, March 11, 2015, accessed June $14,2016$.

http://www.aljazeera.com/indepth/features/2015/03/norway-prison-bars-trust-150303121441430.html.

McLeod, Susanna. "Kingston's solid foundation." The Whig. March 24, 2010, accessed May 3, 2016.

http://www.thewhig.com/2010/03/24/kingstons-solid-foundation.

Pfaff, John F. "The Causes of Growth in Prison Admissions and Populations." SSRN Electronic Journal 28, no. 4 (July 20, 2012 ): 5-11. 
Seymour, Andrew. “Stats Show Bail Granted for Nearly All Who Ask, but Still Too Many Remanded in Custody, Critics Complain.” Ottawa Citizen, June 19, 2016. accessed June 27, 2016, http://ottawacitizen.com/news/local-news/stats-show-bail-granted-for-nearly-all-who-ask-but-still-too-many-remand ed-in-custody-critics-complain.

Sutcliffe, Mark. “One day, we'll factor mental illness in to our criminal justice system.” Ottawa Citizen, June 9, 2016, accessed June 27, 2016.

http://ottawacitizen.com/opinion/columnists/sutcliffe-one-day-well-factor-mental-illness-in-to-our-criminal-justice-system.

Lappi-Seppälä, Dr. Tapio. “Controlling Prisoner Rates: Experiences from Finland.” Accessed May 09, 2016.

http://www.unafei.or.jp/english/pdf/RS_No74/No74_05VE_Seppala1.pdf.

London-Weinstein, Anne. “Weinstein: End jail segregation of the mentally ill.” Ottawa Citizen, June 2, 2016, accessed June 27, 2016. http://ottawacitizen.com/opinion/columnists/weinstein-end-jail-segregation-of-the-mentally-ill.

McLeod, Susanna. "Dickens Thought Kingston 'a Very Poor Town." The Whig. August 20, 2013, accessed May 10, 2016. http://www.thewhig.com/2013/08/20/dickens-thought-kingston-a-very-poor-town.

Mehta, Diana. “Trudeau Government Considers Reopening Prison Farms Shut down in 2010.” July 10, 2016, accessed July $13,2016$.

http://www.theglobeandmail.com/news/national/trudeau-government-considers-reopening-prison-farms-shut-down-in-2010/article30844975/.

"MLK Week." New York University. Accessed May 11, 2016.

https://www.nyu.edu/life/events-taditions/mlk-week.html.

“Most of Canada's Prisoners Have Never Been Convicted of Anything. Why Are They in Jail?." The Globe and Mail. July 17, 2015 , accessed July 14, 2016.

http://www.theglobeandmail.com/opinion/editorials/most-of-canadas-prisoners-have-never-been-convicted-of-anything-why-are-they-in-jail/article2555959

"New Hall Prison Information." Justice. Updated August 30, 2013, accessed July 02, 2016. http://www.justice.gov.uk/contacts/prison-finder/new-hall

"Our Mission Is Transformation." Growing Change. July/August 2011, accessed May 02, 2016. http://www.growingchange.org/.

Palmer, Bryan D. “Kingston Mechanics and the Rise of the Penitentiary, 1833-1836." York University Journals 13, no. 25: 8-13.

“Penitentiary Stone Quarry.” Stone. Accessed June 14, 2016, http://www.stoneskingston.ca/penitentiary-city/penitentiary-stone-quarry/.

Piché, Justin. "Justin Piché: Orange Need Not Be the New Black." The Ottawa Citizen, June 10, 2014, accessed June 15.

http://ottawacitizen.com/news/world/justin-piche-orange-need-not-be-the-new-black.

Piché, Justin. "Kingston Penitentiary Tours Problematic, Argues Criminology Prof." CBC News. June 17, 2016, accessed May 10, 2016.

http://www.cbc.ca/news/canada/ottawa/kingston-penitentiary-tours-problematic-1.3636838.

"Reclaim - Attain - Sustain." Growing Change. February 6, 2015, accessed July 14.

2016, http://www.growingchange.org/reclaim-attain-sustain/.

Reilly, Emma. "The 'pen' of Kingston past." The Queen's Journal. October 14, 2005, accessed July 01, 2016.

http://www.queensjournal.ca/story/2005-10-14/features/pen-kingston-past/. 
Rugge, Tanya and Terri-Lynne Scott. “Restorative Justice's Impact on Participants' Psychological and Physical Health.” Public Safety Canada, November 2009, accessed June 02. 2016, http://www.publicsafety.gc.ca/cnt/rsrcs/pblctns/2009-03-rjp/2009-03-rjp-eng.pdf.

Schenwar, Maya. Locked Down, Locked out: Why Prison Doesn't Work and How We Can Do Better. United States: Berrett-Koehler Pub, 2014.

Schwartz, Daniel. "Kingston Pen Closing Recalls Dark History." CBC News Canada. September 26, 2013, accessed May 10, 2016, http://www.cbc.ca/news/canada/kingston-pen-7-things-to-know-about-canada-s-notorious-prison-1.1865605.

"Sustainability." City of Kingston. 2016, accessed July 14, 2016. https://www.cityofkingston.ca/residents/environment-sustainability/sustainability.

Taylor, C. J. "The Kingston, Ontario Penitentiary and Moral Architecture." Social History 12, no. 24 (1979).

"The open prison Kerava (Finland) - February 2015." De Tour Buissonnier. April 05, 2016, accessed May 10, 2016.

https://detourbuissonnier.wordpress.com/2016/04/05/la-prison-ouverte-de-kerava-finlande-fevrier-2015/.

Tran, Mai. "Inmates Build a Sense of Purpose While Creating a Playhouse Entry." Los Angeles Times. August 31, 2004, accessed May 11, 2016. http://articles.latimes.com/2004/aug/31/local/me-playhouse31.

Vidler, Anthony. The Architectural Uncanny: Essays in the Modern Unhomely. Cambridge, Massachusetts: M.I.T. Press, 1992.

White, Patrick. "Report Gives Diagnosis of Poor Health in Canadian Prisons." Globe and Mail, March 14, 2016, accessed June 15, 2016. http://www.theglobeandmail.com/news/national/report-gives-diagnosis-of-poor-health-in-canadian-prisons/article29226606/.

Wang, Knut Egil and Moment. “Inside Norway's Halden Prison.” The Story Institute. Accessed July 14, 2016, http://www.thestoryinstitute.com/halden/.

"Wanted: ideas for the future of former Kingston Penitentiary and Portsmouth Olympic Harbour." May 31, 2016, accessed July 1, 2016

"https://www.cityofkingston.ca/-/wanted-ideas-for-the-future-of-former-kingston-penitentiary-and-portsmouth-olympic-harbour.

“Welcome to Halden Fengsel." Halden Fengsel. April 1, 2016, accessed May 14, 2016. http://haldenfengsel.no/.

"Welcome to Helsinki Open Prison Suomenlinna Unit." The Scottish Government. Accessed May 02, 2016. http://www.gov.scot/Resource/Doc/925/0059982.pdf.

Wright, Tom. "Introducing the Carlo Scarpa Monograph." Phaidon, accessed April 11, 2016.

http://ca.phaidon.com/agenda/architecture/articles/2013/june/26/introducing-the-carlo-scarpa-monograph/.

Wysochansk, Jon. "Prison Programs Aim to Reduce Recidivism, Give Inmates Job Skills." The Morning Journal. June 01, 2014, accessed June 11, 2016. http://www.morningjournal.com/article/MJ/20140106/NEWS/140109535. 